\title{
Influence of Selenium on Bluegill (Lepomis macrochirus ) in Upper Mud River Watershed
}

\author{
Alison M. Anderson \\ West Virginia University
}

Follow this and additional works at: https://researchrepository.wvu.edu/etd

\section{Recommended Citation}

Anderson, Alison M., "Influence of Selenium on Bluegill (Lepomis macrochirus ) in Upper Mud River Watershed" (2011). Graduate Theses, Dissertations, and Problem Reports. 3269.

https://researchrepository.wvu.edu/etd/3269

This Thesis is protected by copyright and/or related rights. It has been brought to you by the The Research Repository @ WVU with permission from the rights-holder(s). You are free to use this Thesis in any way that is permitted by the copyright and related rights legislation that applies to your use. For other uses you must obtain permission from the rights-holder(s) directly, unless additional rights are indicated by a Creative Commons license in the record and/ or on the work itself. This Thesis has been accepted for inclusion in WVU Graduate Theses, Dissertations, and Problem Reports collection by an authorized administrator of The Research Repository @ WVU. For more information, please contact researchrepository@mail.wvu.edu. 
Influence of Selenium on Bluegill (Lepomis macrochirus) in Upper Mud River Watershed

\author{
Alison M. Anderson
}

A Thesis submitted to the

Davis College of Agriculture, Natural Resources, and Design

at West Virginia University

in partial fulfillment of the requirements

for the degree of

\title{
Master of Science \\ in
}

Wildlife and Fisheries Resources

\author{
Patricia M. Mazik, Ph.D., Chair \\ Kyle J. Hartman, Ph.D. \\ Jennifer Fulton, M.S.
}

Wildlife and Fisheries Resources Program

Division of Forestry and Natural Resources

\section{Morgantown, WV \\ 2011}

Keywords: selenium, bluegill, mining 


\title{
Abstract \\ Influence of Selenium on Bluegill (Lepomis macrochirus) in the Upper Mud River Watershed
}

\begin{abstract}
Alison M. Anderson
Selenium based criteria for aquatic ecosystems have been based on water quality measurements, but recently there has been basis to evaluate other aspects, such as whole body, dietary, and sediment levels. Mud River Reservoir, located in Lincoln County West Virginia, receives selenium input from mountain top/valley fill mining activities. The average selenium water levels for the reservoir are above the US EPA water quality standard of $5 \mu \mathrm{g} / \mathrm{L}$ and considered a high hazard for fish dietary consumption based on macroinvertebrate collections. The bluegill population is also a high hazard for selenium influenced reproductive impairment based on bluegill whole body and calculated egg selenium concentrations. However, the wildlife within the watershed are presented with a low hazard of selenium bioaccumulation from the sediments. Bluegill eggs were collected and monitored in the laboratory for deformities and survival in order to evaluate the overall effects of selenium. However, due to water quality issues, no deformities could be recorded for Mud River Reservoir larvae and survivorship could not be determined.
\end{abstract}




\section{Acknowledgements}

First and foremost, I would like to thank my graduate committee, Dr. Patricia M. Mazik, Dr. Kyle J. Hartman, and Jennifer Fulton, for their assistance and guidance during my time at West Virginia University. They have all helped provide me with the tools necessary to complete this project. I would especially like to thank Dr. Mazik for her consistent up-beat attitude and never ending support for this project. I would also like to thank John Howell, without whom this project would not have been possible.

There have been several people that have provided assistance in both the field and in the lab. Particularly, I would like to thank Andy Hafs and Mike Porto for helping with field collections and for sharing valuable lab space. I would also like to thank Melissa O'Neal and Eric Baker for their continued assistant with data entry and, water quality and benthic macroinvertebrate sampling. I would also like to thank Becky Nestor for her assistance on numerous aspects of my graduate career. Finally, I would like to thank all of the other graduate students who have assisted me in any way during my time here at West Virginia University. 


\section{Table of Contents}

List of Tables .........................................................................................................................................

List of Figures....................................................................................................................................................... vi

List of Appendices............................................................................................................................... vii

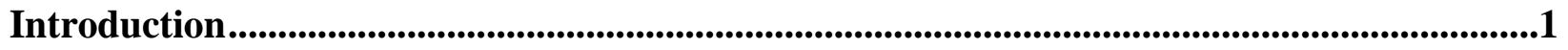

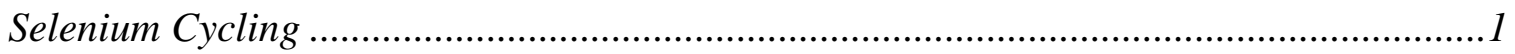

Effects on Fish

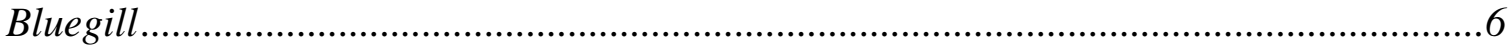

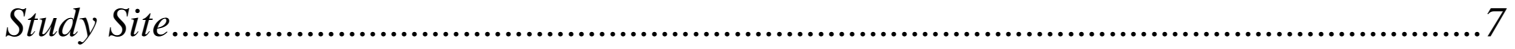

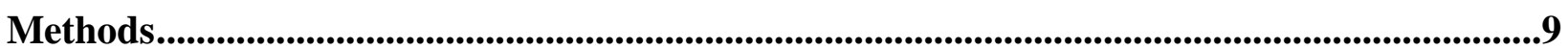

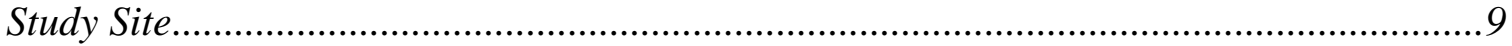

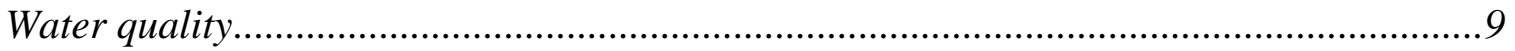

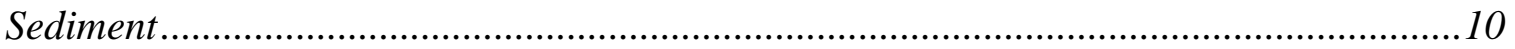

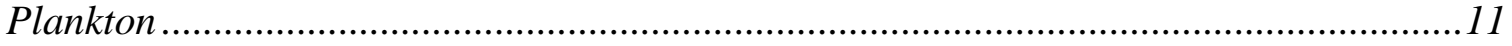

Benthic macroinvertebrates .................................................................................. 11

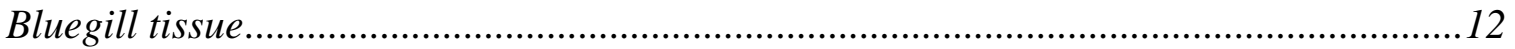

Bluegill larval laboratory study .............................................................................12

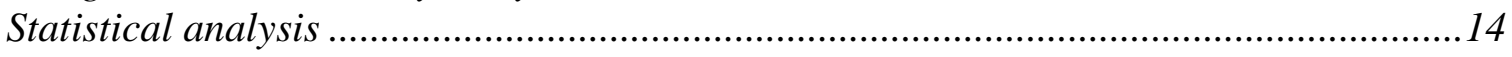

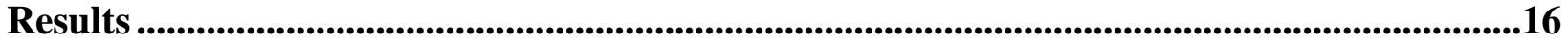

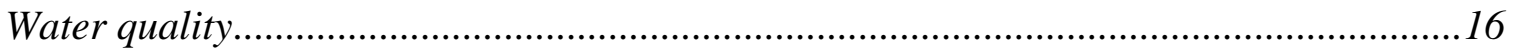

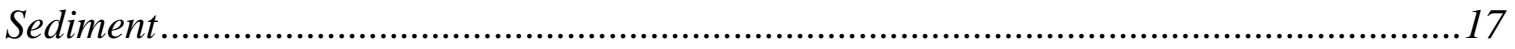

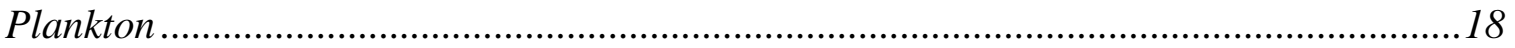

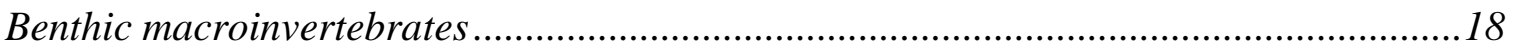

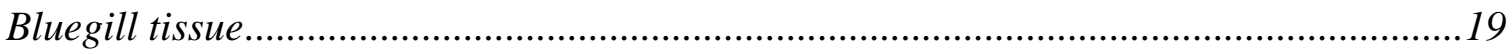

Bluegill larval laboratory study ...........................................................................19

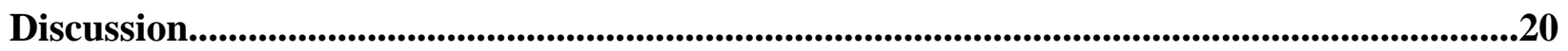

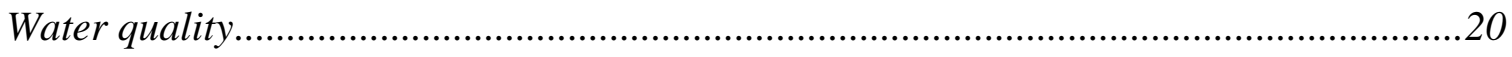

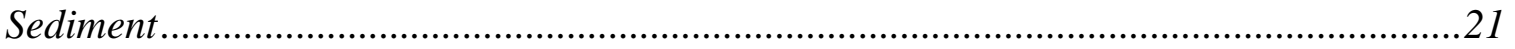

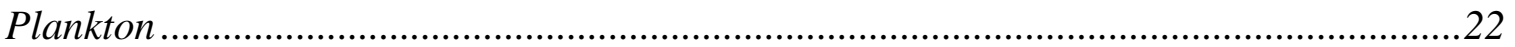

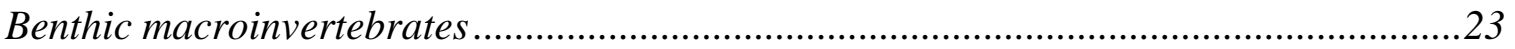

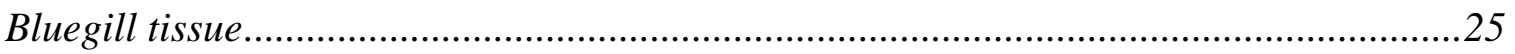

Bluegill larval laboratory study ..............................................................................2

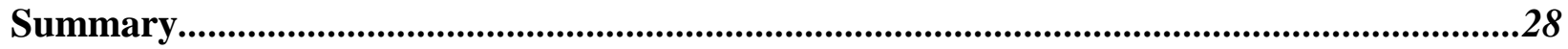

Literature Cited .................................................................................................................................................30 


\section{List of Tables}

Table 1: Sampling site locations with site descriptions for Upper Mud River Watershed and Plum Orchard Lake.

Table 2: Results from principal component analysis (PCA) on water quality data from October 2008 to November 2010

Table 3: Average water quality \pm standard error, for parameters measured once a month from October 2008 to November 2010 for mined and unmined portions of Upper Mud River Watershed and the reference site.

Table 4: Average whole body selenium concentrations \pm standard error for each functional feeding group (Filterers, Gatherers, Scrapers, and Shredders) and composite sample for each site type (Unmined, Mined, and Reference).

Table 5: Mean weight, length, condition factor, relative weight, and selenium levels for bluegill sampled in the reference location and Mud River Reservoir.

Table 6: Mean water quality \pm standard error for the reference and Mud River Reservoir A and $\mathrm{B}$ tanks from the larval laboratory study. 


\section{List of Figures}

Figure 1: Locations of Upper Mud River and Paint Creek Watersheds in West Virginia ...........40

Figure 2: Water quality sampling locations within the Upper Mud River Watershed in Lincoln and Boone counties.

Figure 3: Water quality and benthic macroinvertebrate sampling locations within the reference site.

Figure 4: Stream sediment sampling locations with the Upper Mud River Watershed, which correspond to water quality sites

Figure 5: Reservoir sediment sampling transect locations with the Mud River Reservoir .44

Figure 6: Benthic macroinvertebrate sampling locations with the Upper Mud River Watershed, which correspond to water quality sites

Figure 7: Scatter plot of the first two water chemistry principal components (PCs) with symbols representing site types

Figure 8: Mean stream sediment selenium concentrations for each site type analyzed with a Student's t-test.

Figure 9: Mean reservoir transect sediment selenium concentrations for the top $5 \mathrm{~cm}$ analyzed with an ANOVA

Figure 10: Mean planktonic selenium levels at each site over a 3 month sampling period compared with an ANOVA

Figure 11: Linear regression of the relationship between the log of water selenium and the log of benthic whole body selenium concentrations.

Figure 12: Length frequency histograms for the Mud River Reservoir and the reference sites.

Figure 13: Scatter plot of bluegill whole body selenium concentrations and weight symbolized by sampling location. 


\section{List of Appendices}

Appendix I. Juvenile bluegill survey summary from September 2009 .......................................53

Appendix II Larval light trap summary conducted in July 2009 and 2010 ....................................54 


\section{Introduction}

Selenium is a naturally occurring metalloid which is often associated with coal seams, phosphate deposits, and other mineral formations (Debruyn et al., 2007). Higher concentrations of selenium in the environment are usually linked to mobilization due to irrigation in seleniferous soils, sewage, fly ash from coal combustion, and mining (Hamilton, 2004). In particular, fly ash basins and mining settling ponds can leach, or overflow, allowing selenium to be transported into surrounding waterways.

\section{Selenium Cycling}

The biogeochemical cycle of selenium in freshwater is complex. The multiple oxidation states and chemical forms all interact with organisms producing different biological and toxicological effects (Bowie et al., 1996). There are four oxidation states of selenium, selenite $\left(\mathrm{SeO}_{3}{ }^{-2}\right)$, selenate $\left(\mathrm{SeO}_{4}{ }^{-2}\right)$, selenides, and elemental selenium (Se). Elemental Se is insoluble and poorly assimilated by aquatic plants, but can be found in bacteria, sediments, and suspended in the water column (Canton and Van Derveer, 1997). The two most common forms of aqueous selenium are selenite and selenate. Phytoplankton actively take up these inorganic selenium compounds, but at different short-term rates (Bowie et al., 1996). Initially, selenite is taken up at a faster rate than selenate due to adsorption to cell walls, but over time selenite and selenate are taken up at similar rates (Bowie et al., 1996). Organic selenides are produced from the incorporation of selenite into aquatic plants and other primary producers making selenium readily available in the food chain (Canton and Van Derveer, 1997). Bacteria, commonly associated with sediments, are similar to phytoplankton in terms of uptake and assimilation but their long term uptake rates of selenite continue (Bowie et al., 1996). These microbes are major factors in selenium cycling due to their ability to perform oxidation-reduction reactions and 
recycle selenium that has either adsorbed to detritus, clay particles, or inorganic particulates (e.g. iron), or from the decomposition of selenium laden organisms (Bowie et al., 1996).

Zooplankton obtain some selenium from their aqueous habitat, but the consumption of phytoplankton and bacteria is the major form of uptake (Bowie et al., 1996). For example, protozoans and cladocerans are highly efficient at assimilating selenium (35 and 44 to 72 percent, respectively) from their prey (Sanders and Gilmour, 1994). Macroinvertebrates and fish accumulate selenium from absorption through the epidermis or the gills, but the major pathway is the consumption of selenium laden prey or detritus (Hamilton, 2003).

Overall, selenium can be directly consumed or absorbed by organisms, can be adsorbed to particulates or overlying sediments, or remain in its aqueous forms (Lemly, 1997). The processing of selenium is dependent on the waterbody being studied, along with the biotic and abiotic community present. The immobilization of selenium occurs when it has been removed from the water column by the reduction of selenate to selenite where it then binds to clay and organic particulates, or reacts with iron to form a precipitate (Lemly,1999). The precipitates then settle, along with any decomposing plant and animal tissues, allowing further microbial processing of selenium (Lemly, 1999). Through further sedimentation, selenium can become buried and removed from the water column for varying amounts of time. Sedimentation and microbial actions are most efficient in lakes, pools, wetlands, and other static water habitats, where $90 \%$ of the selenium is contained in the top few centimeters of sediment (Lemly and Smith, 1987). Selenium is then remobilized into the food chain by plant root absorption and consumption by benthic invertebrates and bottom-feeding fish. This constant cycling between sediments and benthic organisms can keep elevated levels of selenium in a system even when water concentrations are low. 


\section{Effects on Fish}

In small doses, selenium is important in the diet of fish to perform several functions that optimize health. The main function selenium serves is protecting DNA, lipids, and proteins from free radicals generated during metabolism (Rider et al., 2009). Fishes low in selenium tend to suffer from loss of coordination in muscle movements (Rider et al., 2009), reduced growth, and reduced immune response (Wang and Lowell, 1997). In aquaculture, it is important to supplement feed with selenium to help physically stressed fish ward off disease $[0.35 \mathrm{mg} / \mathrm{kg}$ for rainbow trout (Oncorhynchus mykiss) and $0.40 \mathrm{mg} / \mathrm{kg}$ for channel catfish (Ictalurus punctatus), (Wang and Lowell, 1997, Rider et al., 2009)], maintain growth (Rider et al., 2009) and increase survival in larval fish (Hamilton, 2004; Hamre et al., 2008).

Selenium toxicity is also affected by the presence of other trace metals. In Atlantic salmon (Salmo salar), dietary copper has been shown to reduce selenium concentrations in the liver. This occurs when selenium forms an insoluble complex with copper in the intestine of the salmon, preventing selenium from being absorbed into the liver (Lorentzen et al., 1998).

However, the more well known interaction is with mercury. The presence of selenium interferes with mercury transfer through the food web (Hamilton, 2004). The results of two lake experiments both confirmed that selenium, at low levels, decreased mercury accumulation in fish, but there is a threshold at which selenium is also bioaccumulated (Hamilton, 2004).

Even though selenium is essential at low levels, it can be very toxic at slightly higher levels affecting each life stage of a fish differently. In adult fish, when elevated concentrations of selenium are present in water, the lamellae of the gills can become swollen due to dilation of the sinusoids (Sorensen et al., 1984). This constriction of the blood vessels impairs blood flow, 
which impairs gas exchange efficacy of the gills (Lemly, 2002). Not only does selenium affect gas exchange, but it also has the ability to bind to hemoglobin in the red blood cells rendering them unable to carry oxygen (Lemly, 2002). This reduced oxygen flow to the rest of the body can negatively affect metabolic stress responses in the fish (Lemly, 2002). Selenium has also been shown to induce cataracts in laboratory mammals and fish populations. Edema, which can cause protruding eyeballs, is another sign of selenium toxicity in which fluid builds up in the body and head cavity (Ellis et al., 1937). Body fluids are able to build up in cavities due to the increased permeability of cell membranes, which is caused by faulty selenium proteins (Lemly, 2002).

Selenium can have immediate effects on the current fish population, but adverse effects can be passed from parent to progeny. Adult fish, specifically females, accumulate selenoproteins into their ovaries affecting their reproductive potential and the quality of their offspring. The toxicity of selenium to larvae fish is due to selenium being biochemically similar to sulfur. When selenium is in excess, cells cannot discriminate between the two compounds. So, when they produce proteins for growth and repair, selenium can be substituted for sulfur. This results in dysfunctional amino acids, or proteins, based on an incorrect tertiary structure. In fish, these deformed proteins are accumulated in metabolically active tissues like the gonads, liver, and kidney. When excess dietary selenium is stored in the ovarian tissues, the selenium can then be incorporated into the eggs, particularly in the yolk sacs (Lemly, 1997). When the eggs hatch, the larvae use up the yolk quickly as a form of energy and protein supply for growth. However, the protein supply has been altered due to selenium being substituted for sulfur during protein synthesis. The distorted proteins can lead to improper development or absence of body parts, particularly in the skeleton, fins, head, and mouth, which are all examples of teratogenic 
deformities (Lemly, 1997). These deformities may not have direct lethal consequences on the adult fish, or hatching success, but they can act as permanent physical biomarkers of toxicity (Gillespie and Baumann, 1986).

Spinal deformities in fish are easily recognized and are accepted as an indication of selenium contamination (Lemly, 1997). There are three major types of teratogensis: lordosis, scoliosis, and kyphosis. Lordosis consists of a concave curvature of the lumbar region, while kyphosis is the convex curvature of the thoracic region of the spine. Scoliosis is demonstrated by a lateral curvature. Other non-spinal teratogenic deformaties include missing fins, missing or deformed opercles, disfigured head, and deformed mouth (Lemly, 1997). These abnormalities are usually seen in multiples. Mortality of these fish is usually high if the defects impair critical body functions which could increase the chances of being eaten, or not obtaining enough food (Woock et al., 1987).

There are laboratory studies that have linked elevated levels of selenium to these specific malformations, but there are only a handful of field studies that have also showed this connection. A power plant cooling reservoir (Belews Lake) in North Carolina was contaminated with selenium from a coal-fired power plant's effluent during the mid-1970's with average water concentrations of $10 \mu \mathrm{g} / \mathrm{L}$. From these elevated concentrations, selenium was able to bioaccumulate in the food chain resulting in tissue damage, reproductive impairment, and subsequent population loss in 19 of the 20 species present (Lemly, 1985; Sorensen et al., 1984). The fishes within Belews Lake showed swollen gill lamellae, cataracts, edema, teratogenic deformities, along with numerous internal impairments (Lemly, 2002). After ending the selenium laden effluents, an extensive stocking program was implemented, and monitoring a decade later showed a decrease in all ecosystem components with water quality being near 
reference levels $(<1 \mu \mathrm{g} / \mathrm{L})$. Even though water concentrations had decreased, there were still high insistences of teratogenesis due to high selenium levels in the sediments and benthic invertebrates (Lemly, 2002). From the Belews Lake case study, Lemly (1995) published toxic effect thresholds (TET) for selenium in order to assess the impact a level of contamination might have on aquatic life. There are selenium TET's for several aspects of the ecosystem (water, sediment, dietary, or tissues) at which toxic effects have been observed in the field or in a laboratory setting. Also, the type of system (stream, reservoir, or wetland) involved must be considered when evaluating the TET for similar ecosystem components.

\section{Bluegill}

Members of Family Centrarchidea are common in North America. Within this family, there are 30 species which belong to four genera, Pomoxis (crappie), Micropterus (bass), Ambloplites (rock bass), and Lepomis (sunfish). The most well known and widely distributed members are the larger game fish. In particular, sunfish are currently being used in aquaculture as a food source for both humans and other hatchery fish. Sunfish can be found in ponds, lakes, and slow moving rivers and streams. For this study, we will focus on the bluegill sunfish

\section{(Lepomis macrochirus).}

Bluegills are recognized by their laterally compressed body with a spiny anterior dorsal fin and a soft posterior dorsal fin. They have pointed pectoral fins, which are located directly above the pelvic fins. Other distinguishing characteristics are a large blue dot on the operculum, light vertical striping on the sides, along with a dark blotch at the base of the posterior dorsal fin.

Bluegill commonly demonstrates colonial nest building (Gross and MacMillan, 1981).

First, the male, using the flutter of his tail, creates a depression in the sediment resulting in a ring shaped nest (Gross and MacMillan, 1981). These nests are often found along the shoreline in 
sunny areas. The male will then circle his nest, protecting it from other males and trying to attract females through a series of low grunts (Avila, 1975; Gross and MacMillan, 1981). This behavior is usually seen in late spring or early summer when the water temperature is between 20 and $29^{\circ} \mathrm{C}$. One to many females may lay their eggs on a selected nest. The male then fertilizes the eggs, while the female moves to a different nest (Avila, 1975; Becker, 1983). In this relationship, the males are the protectors of the nest. Once the eggs are fertilized they water harden and sink to the bottom of the nest. The males circle the nest to keep away predators and fans the eggs keeping them aerated and free from sedimentation, bacteria, and other waste. The male continues this behavior until the eggs hatch, which can be 2 to 6 days after fertilization depending on light and water temperature (Toetz, 1966; Smith, 1975; Beard, 1982).

The next life stage is of importance to this study since this is when the yolk sac is consumed by the larval fish. While the larvae use up the yolk sac, the fish begin to develop their pigmentation, notochord, digestive system, and fins. During this vital time in development, excess selenium in the yolk impedes proper growth and development. Two to 7 days after hatching, the swim-up stage occurs. During this time, the larval fish no longer have a yolk sac, so they must switch from endogenous to exogenous feeding. If the larvae are unable to swim up into the water column due to selenium induced deformities, they will not be able to feed which will result in mortality. Over time, a decrease in juveniles could lead to a decrease in overall population size and health.

\section{Study Site}

Mud River is a portion of the Upper Mud River watershed which is located within the Lower Guyandotte River watershed. The study area is contained in Lincoln and Boone Counties, 
West Virginia (Figure 1). The 124 ha reservoir is located in the Upper Mud River Wildlife Management Area. Upper Mud River Reservoir was earthen dammed in 1995 for flood control, but since then it has grown into a catch and release largemouth bass (Micropterus salmoides) fishery. With an average depth of 4.5-6 meters, which is dominated by woody debris and submerged aquatic vegetation, the reservoir also houses bluegill, channel catfish, and crappie. There are two forks within the Upper Mud River watershed. The main stem of the Mud River is greatly affected by the mountain top/valley fill mining operations of the Hobet 21 mine. Lowsulfur coal has increased the need to use draglines to extract excess materials on top of and in between coal seams. The waste material is then dumped into adjacent valleys. Along with physically altering the surrounding environment due to sedimentation and temperature fluctuations, these mining practices have the ability to mobilize metals such as copper, lead, zinc, and selenium into the waterways (Lohner et al., 2001). The Left Fork of the Mud River flows into the opposite end of the Mud River Reservoir and is not impacted by current mining practices.

Plum Orchard Lake, which is within the Plum Orchard Lake Wildlife Management Area, is located in Fayette County, West Virginia (Figure 1). This 81.75 hectare lake has $10.5 \mathrm{~km}$ of shoreline with a mean depth of 5 meters. The shoreline is dominated by aquatic vegetation which provides the local populations of bluegill, largemouth bass, channel catfish, and white crappie (Pomoxis annularis) with habitat.

The objectives of this study were: 1) to determine the effects of selenium on the aquatic ecosystem of the Upper Mud River Watershed, WV and 2) to determine the effects of selenium on the survival of bluegill larvae. 


\title{
Methods and Materials
}

\author{
Study Site
}

There were 24 total sampling locations on the Mud River and its tributaries for water quality, benthic macroinvertebrates, and sediments (Table 1). The Mud River Reservoir, as a whole, was used for plankton, bluegill tissue, and bluegill egg collection. Within the watershed, there are mined and unmined portions (Figures 2-6). The mined portion contained 16 sites within the Hobet 21 mine boundary and downstream (MudR04-MudR10 and MudR16-18, Ballard Fork, Berry Branch, Stanley Fork, and Sugartree Branch), including the outflow (MudR15) and one site on the reservoir (MudR11). The unmined portion consists of the 3 sites upstream of the mine boundary (MudR01-MudR03), one tributary site (Upton) outside the mine boundary, and 4 sites on the left fork of the watershed (MudR12-MudR14 and MudR19). Plum

Orchard Lake (Figure 1; Table 1) is a reservoir, located in the Paint Creek Watershed, unaffected by mining, so there are no anthropogenic selenium inputs and will serve as the reference for the water quality, benthic macroinvertebrates, fish tissue, and plankton samples.

\section{Water quality}

The 15 mainstem sites (MudR1-15) and 5 tributary sites (Ballard, Berry, Stanley, Sugartree, and Upton) (Figure 2) along with 2 reference sites on Plum Orchard Lake (Figure 3), were sampled once a month, from October 2008 to November 2010 (for the mainstem and reference sites), and June 2009 to November 2010 for the 5 tributary sites. At each site, a YSI 556 handheld multi-probe meter (Yellow Springs Instruments, Yellow Springs, Ohio) was used to measure temperature, dissolved oxygen, specific conductivity, and $\mathrm{pH}$. Unfiltered $500 \mathrm{~mL}$ water samples grabs were collected and analyzed for total iron, total selenium, sulfates, total 
acidity, total alkalinity, hardness, and total dissolved solids each month and in December 2009, total suspended solids were added to the analysis. In addition, a $250 \mathrm{~mL}$ sample was collected and treated with $1 \mathrm{~mL}$ sulfuric acid for analysis of total organic carbon. In order to analyze for dissolved iron and dissolved selenium, a 250-mL water sample was collected and filtered through a $0.45 \mu \mathrm{m}$ pore sized mixed cellulose ester membrane filter and treated with $1 \mathrm{~mL}$ of nitric acid. Water samples were kept below $4^{\circ} \mathrm{C}$ until analysis by Research Environmental and Industrial Consultants, Inc. (REIC, Beckley, West Virginia) and West Virginia University Analytical Laboratories was conducted following EPA laboratory methods.

\section{Sediment}

In order to evaluate the extent in which selenium has been incorporated into the benthos, sediment sampling was performed in July 2009 by Stantec, Inc (Lexington, KY). There were 13 stream sampling sites which corresponded with water quality sites (Figure 4). A small shovel, $20 \mathrm{~cm}$ wide by $24 \mathrm{~cm}$ long, was used to collect sediments from these stream locations. In order to minimize operator bias, all substrate from a pre-determined depth of $10 \mathrm{~cm}$ was removed from the stream bed and some of the water was drained before placing it into a plastic bag. In the reservoir, there were 5 transects (Figure 5) in which a dive team was used to collect sediment cores. There were 3 sampling locations along each transect (left, middle, and right). At the left and right sampling locations, a 2 and $5 \mathrm{~cm}$ core was taken. At the middle location, a 5 and $20 \mathrm{~cm}$ core was taken. The $20 \mathrm{~cm}$ core was analyzed in $5 \mathrm{~cm}$ increments. Only the top $5 \mathrm{~cm}$ samples were used in analysis since this layer corresponds to the biologically active layer and represents the most recent deposition in the reservoir. All sediment samples were dried and analyzed for total organic carbon, total selenium, ammonia nitrogen, $\mathrm{pH}$, and percent moisture by REIC. 


\section{Plankton}

Incorporation of selenium into primary produces is a major entry point for selenium into the aquatic food chain. In order to evaluate the amount of selenium that has been integrated into the planktonic community, plankton tows were done with two $250 \mu \mathrm{m}$ plankton nets in July, August, and September 2010. There were two sites at Mud River Reservoir, one near the beach where the mined mainstem is located and the other near the unmined left fork. One reference site was used at Plum Orchard Lake near the boat ramps. Each tow was conducted for at least 10 minutes and lasted no longer than 20 minutes. Tow duration was varied to achieve at least a $1 \mathrm{~g}$ sample as required for laboratory measurements of total selenium. A surface and mid-water column sample was taken at each site. The contents from both of the nets at one depth were combined and preserved in $95 \%$ ethanol. The plankton was analyzed for selenium concentrations in milligrams per kilogram by REIC.

\section{Benthic macroinvertebrates}

Yearly benthic macroinvertebrates samples were collected after complete leaf fall each autumn. The first sampling period was November 2009. There were 11 sites on Mud River (Figure 6), along with 2 sites at Plum Orchard Lake, which occurred on a stream flowing into and out of the reservoir (Figure 3). At each site, 4 samples were taken with a kick net (335 x 508 mm with $500 \mu \mathrm{m}$ mesh) at targeted riffles, combined in a composite for one site, and preserved with $95 \%$ ethanol. Individual macroinvertebrates were sorted and analyzed by functional group (predator, shredder, filterer, gatherer, or scraper) for total selenium (mg/kg) by REIC. The second sampling was done in November 2010 at the same locations from the previous year. Six 
kick samples were taken in 2010 from the same sites to ensure enough mass for the functional feeding group analysis ( $1 \mathrm{~g}$ of tissue).

Bluegill tissue

Adult bluegill were collected on two sampling dates (June 2009 and 2010) during nest guarding of their spawning period by boat electrofishing. A total of 118 and 86 bluegills were collected from Mud River Reservoir and the reference location, respectively. All fish collected were sexed, kept on ice and transported to REIC for analysis of whole body selenium by dry weight. From the individuals collected, 32 and 13 from Upper Mud River Reservoir and the reference location, respectively, had gonad tissue analyzed separate from the whole body analysis.

In September 2009, a survey was conducted to check for any deformities in juvenile bluegill in both the Mud River Reservoir and the reference site. Four fyke nets were set overnight (approximately $20 \mathrm{hrs}$ ) at both the reference site and Mud River Reservoir. After fyke nets from both sites were pulled, night time electrofishing was conducted with a Smith-Root electrofishing boat (Smtih-Root, Inc., Vancouver, WA) with a pedal time of 3,600 seconds. Lengths were taken for all fish collected from fyke nets and electrofishing and checked for any external deformities (i.e. spinal curvatures, missing fins, and deformed mouth parts).

\section{Bluegill larval laboratory study}

In order to assess larvae survivorship, bluegill nests were collected from Upper Mud River Reservoir and from the reference location in June 2009 and 2010. In 2009, entire redds were collected, including sediments and plant material. However, due to elevated ammonia levels larval fish did not survive past 4 days after nest collection. Therefore, in 2010, only shells, 
rocks, and branches with eggs attached were removed by hand. In both years, individual redds were placed into plastic bags containing water from the site. Each bag was then inflated with oxygen and placed into a cooler for transport to WVU wet lab. Upon arrival at the lab, each piece of material collected, in 2010, from a nest was examined under a dissecting scope and the number of eggs attached was counted.

In order to assess the impact selenium has on bluegill larvae, two different tanks were used to monitor swim-up success and total survival. Swim-up success, or the switch to exogenous feeding, was examined within the B tanks and were examined 9 days after hatching. Total survival was monitored with the A tanks by an early life stage test for chronic toxicity with the end point being 28 days after hatching. The nest materials collected were placed into either an aerated 14.4 L (A tank) or a 6.6 L (B tank) plastic aquarium which contained water from their original location. For example, one nest from the reference site was placed into an A and B tank containing reference water and the same was repeated for Upper Mud River Reservoir nests. Approximately one-third of the materials collected from a nest were placed into a B tank. Not every nest was able to be split into a sub-tank based on the total number of eggs in the nest. If this separation would have resulted in less than 10 eggs in either tank, a B tank was not used and all the eggs were placed into an A tank. A total of 18 and 15 nests were collected from Upper Mud River Reservoir ( $n=802$ eggs) and reference site ( $n=6168$ eggs), respectively. From those original nests we were able to split in Mud River Reservoir nests into 14 B tanks and the reference site into $9 \mathrm{~B}$ tanks. At the end of the specified time periods for each set of tanks, the number of surviving larvae where counted and swimming was monitored for any deformities.

Ammonia, nitrite, alkalinity, and hardness were monitored with a $\mathrm{HACH}$ portable spectrophotometer model DR2700 (Loveland, CO). Ammonia readings were taken daily while 
nitrite, alkalinity, and hardness were taken once a week. A YSI was used to take temperature, dissolved oxygen, and $\mathrm{pH}$ on a subset of 10 randomly selected tanks each day resulting in each tank being sampled biweekly.

\section{Statistical analysis}

Statistical analyses were performed using the R Project for Statistical Computing Version 2.11.1 ( $\mathrm{R}$ Development Core Team, 2010) with a 95\% $(\alpha=0.05)$ level of confidence. Data is presented as the mean \pm standard error. Data that failed the Shapiro-Wilkes normality test were $\log (10)$ transformed prior to use.

Water quality parameters taken within the reservoir were compared with the reference site by a Student's t-test. In order to determine if the mine is producing significant effects on the watershed, a principle component analysis was used to generate independent principle components (PC) to account for the variability in the water quality dataset. Principal components with an eigenvalue $\geq 1$ were determined to be statistically significant from the principal component analysis (McCune and Grace, 2002). Factor loadings were calculated for each PC by correlating the principal component scores from the first two PC's with the original water quality data. The first two PC's were plotted against each other to represent inter-site differences. Site types replaced individual site locations to help visually compare the water chemistry differences between mined, unmined, and reference sites. An analysis of variance (ANOVA) was then used to detect any statistical differences between the principle component scores against suggested site type (mined, unmined, and reference). A Tukey's Honest Significant Difference (HSD) post hoc test was then used to determine which site types were statistically different. 
Stream sediment selenium concentrations were compared with a Student's t-test between the mined and unmined sampling locations. For the reservoir transect samples, the top $5 \mathrm{~cm}$ of the cores collected for each location were averaged and compared based on total selenium concentrations with an ANOVA. A Tukey's HSD was then conducted to determine which transects were significantly different within the reservoir. Plankton selenium concentrations at each site were evaluated with a two-way ANOVA with site type and depth. A Tukey's HSD was performed to test for differences between site 1 (mined), site 2 (unmined), and the reference.

Selenium has the ability to bioaccumulate in benthic macroinvertebrate tissues at high concentrations which can vary by functional feeding groups. In order to evaluate the effects site type has on each functional feeding groups whole body selenium concentrations, we ran a twoway ANOVA on site type (mined, unmined, and reference) with functional feeding group (FFG) as a co-variate. A one-way ANOVA was also conducted to test for the differences in selenium concentrations within each site type for each functional feeding group.

Since selenium can induce metabolic stress responses in fish, we wanted to look at the overall condition of bluegill collected. Lengths of the bluegill collected during the 2009 sampling season (both the survey and individuals collected for tissue analysis) were plotted in a length-frequency histogram. In order to evaluate the weight at specific lengths for individual fish collected in 2009, Fulton Condition Factors (K) were calculated with the equation

$$
\mathrm{K}=\frac{\text { Weight }(\mathrm{g})}{\text { Length }(\mathrm{mm})^{3}} * 10^{5}
$$

Relative weights (Wr) (Wege and Anderson, 1978) were also calculated for the individuals collected from Mud River Reservoir and the reference, from the 2009 tissue analysis. Relative weights were calculated from a linear length-weight relationship for each site following the 
methods of Wege and Anderson (1978). The mean conditions and relative weights from each location were compared with a Student's t-test. Whole body and gonad selenium concentrations for bluegill were analyzed by a Student's t-test between Mud River Reservoir and the reference. Not all bluegill females collected had eggs present in their ovaries; therefore did not have enough gonad material present to run a selenium analysis. Instead, bluegill egg selenium concentrations were calculated from bluegill whole body concentrations with the following equation (Lemly and Smith, 1987; Skorupa et al., 1996)

Fish egg $\mathrm{Se}=$ Whole body Se x 3.3

Water quality for the larval bluegill study was compared between Mud River Reservoir and the reference with a Student's t-test. Percent survival and swim-up were determined by counting the number of individuals at the end of their respective time period and divided by the total number of eggs collected from that site. The percentages were then compared with a Student's t-test. Lastly, a multiple regression analysis was performed to determine the relationships among selenium concentrations in water, sediments, and benthic macroinvertebrate tissues from Mud River to determine if aqueous or sedimentary selenium had a greater affect on benthic macroinvertebrate whole body concentrations.

\section{Results}

Water Quality

The PCA identified two statistically significant principal components (PC1 and PC2) accounting for $83 \%$ of the total variation in the water quality dataset. PC1 shows decreasing factor loadings that correspond to increasing alkalinity, hardness, sulfates, TDS, total selenium, and conductivity, while an increasing factor loading demonstrates increasing dissolved iron (Table 2, Figure 7). PC2 shows a decrease in factor loadings that corresponds to a decrease in 
total iron (Table 2, Figure 7). The ANOVA on the PC scores showed a significant difference between suggested site types. Further analysis, with a Tukey's HSD, showed that the mined sites were statistically higher than the reference and the unmined sites, while the unmined and reference sites were not statistically different.

Individual water quality variables for each site type were then analyzed with an ANOVA. All variables, except for total organic carbon and dissolved oxygen, produced significant differences (Table 3). Mean conductivity, hardness, alkalinity, total dissolved solids, and sulfates were significantly higher at mined sites than unmined sites with the reference site being the lowest (Table 3). Similarly, mean pH and total selenium were significantly higher at the mined sites than both the unmined and reference sites (Table 3). Mean temperatures were significantly higher at the reference site than both the mined and unmined sites (Table 3). Total iron at the unmined sites were similar to both the mined site and the reference site, but the mean concentrations at the mined sites were significantly higher than the reference site (Table 3). Finally, dissolved iron was significantly higher at the reference site than the unmined and mined sites, with the mined sites being the lowest (Table 3).

\section{Sediments}

Stream sediment selenium concentrations were not statistically different at mined $(0.463 \pm 0.165 \mu \mathrm{g} / \mathrm{g} \mathrm{DW})$ and unmined $(0.173 \pm 0.067 \mu \mathrm{g} / \mathrm{g} \mathrm{DW})$ sites (Figure 8). Transect sediment cores for the top $5 \mathrm{~cm}$ for each transect, were not statistically different when compared with a one-way ANOVA (Figure 9). 


\section{Plankton}

Plankton concentrations, examined with a two-way ANOVA were statistically different between sites with varying depths. A Tukey's HSD showed the mean selenium whole body concentrations at the reference site $(1.31 \pm 0.21 \mu \mathrm{g} / \mathrm{g} \mathrm{DW})$ was significantly lower than the Mud River Reservoir site 1, which is mined, (11.93 $\pm 0.08 \mu \mathrm{g} / \mathrm{g}$ DW) and 2, which is unmined, (7.07 $\pm 0.12 \mu \mathrm{g} / \mathrm{g}$ DW) while the two Mud River Reservoir sites were not statistically different (Figure 10). The selenium levels did differ significantly with depth in which mid depth sites were consistently higher than the surface samples.

\section{Benthic macroinvertebrates}

A two-way ANOVA demonstrated significant differences in selenium concentrations in the benthic macroinvertebrates overall and in some functional feeding groups between mined, unmined, and reference sites (Table 4). Composite benthic macroinvertebrate total selenium concentrations were significantly higher at mined sites when compared to reference and unmined sites. However, unmined and reference sites were not statistically different. Each functional feeding group was examined with predators, filterers, gatherers, shredders, and scrapers at unmined sites being significantly lower in whole body selenium than those at mined sites (Table 4). Selenium concentrations in gatherers, predators, and shredders at unmined sites, were not statistically different than those at the reference sites. Sufficient mass was not obtained at the reference site for filterers and scrapers to run selenium whole body analysis and was not used in the statistical analysis. The log of the water and sediment selenium concentrations was highly correlated $\left(r^{2}=0.77\right)$ with the log of the benthic macroinvertebrate whole body selenium concentrations within the Mud River Watershed. However, only aqueous selenium levels 
contributed significantly to the relationship. The linear model with only the log of water selenium concentrations was correlated with the log of benthic macroinvertebrate average whole body selenium concentration $\left(\mathrm{r}^{2}=0.76\right)$ (Figure 11).

\section{Bluegill Tissues}

Evaluations of the bluegill populations within Mud River Reservoir and the reference site showed some overall population differences in terms of condition and tissue selenium concentrations. Bluegill collected in 2009 from the reference site $(n=53)$ ranged from 40 to 180 mm (Table 5; Figure 12). The individuals collected from the Mud River Reservoir ( $\mathrm{n}=195)$ ranged from 20 to $200 \mathrm{~mm}$ (Table 5; Figure 12). Condition factors were significantly higher at the reference site than Mud River Reservoir (Table 5). The mean relative weights were not statistically significantly different between the two sites (Table 5).

Whole body selenium concentrations in adult bluegill were significantly higher in Mud River Reservoir $(20.836 \pm 0.592 \mu \mathrm{g} / \mathrm{g}$ DW) than the reference site $(1.395 \pm 0.036 \mu \mathrm{g} / \mathrm{g} \mathrm{DW})$

(Table 5). Similarly, gonad selenium concentrations from adult bluegill in Mud River Reservoir $(19.72 \pm 1.024 \mu \mathrm{g} / \mathrm{g}$ DW $)$ were significantly higher than the reference site $(2.50 \pm 0.532 \mu \mathrm{g} / \mathrm{g}$ DW) (Table 5). Calculated selenium concentrations in bluegill eggs were statistically higher in Mud River Reservoir bluegill than the reference bluegill (Table 5). Overall, 100\% of the bluegill sampled $(\mathrm{n}=118)$ had selenium concentrations greater than the toxic effect threshold $(5 \mu \mathrm{g} / \mathrm{g}$ DW) for the health and reproductive success of freshwater fish (Figure 13). Results for a juvenile survey conducted in 2009 are found in Appendix I. These results are not included in this thesis.

Bluegill larval laboratory study 
The inherent water quality differences between the Mud River Reservoir and the reference site resulted in some of the differences seen in the laboratory tanks. Mud River Reservoir and Reference A tanks had statistically different temperature, $\mathrm{pH}$, ammonia, and nitrite levels while, the dissolved oxygen did not differ (Table 6). The B tanks had statistically different temperature, dissolved oxygen, $\mathrm{pH}$, and nitrite levels with similar ammonia concentrations (Table 6). Mud River Reservoir and Reference A tank larval bluegill did not survive to the end point (28 days); therefore no deformities could be recorded. Mud River Reservoir B tank larvae did not survive to the end point (9 days). However, Reference B tank larvae showed a 7.8\% survival at the end point ( 9 days). Results for a larval light trap survey conducted in 2009 and 2010 are presented in Appendix II. These results are not included in this thesis.

\section{Discussion}

Water quality

A Principal Component Analysis is a technique used to reduce data to summarize patterns in particular dataset (Merovich et al., 2007). For this study, the PC's that were generated accounted for the majority of the variation seen between each individual site in regards to water quality. By grouping sites into a designated site type and comparing the PC scores, we were able to statistically, and visually, detect differences between mined, unmined, and references sites. This analysis shows that the mine boundary, which delineated mined versus unmined sites, is a good indicator of site type and produces significant water quality differences.

Based on the hazard profile published by Lemly (1995) for water quality, 8 of the 20 water quality sampling sites (MudR7-11, Berry, Stanley, and Sugartree) in the Mud River Watershed had average total selenium above the high hazard category (> $5 \mu \mathrm{g} / \mathrm{L})$. Another 5 
sites (MudR4-6 and 15) fell into the moderate hazard category $(3-5 \mu \mathrm{g} / \mathrm{L})$. All of the sites that fell within these two categories were within or downstream of the mine boundary which includes the reservoir site (site 11) and the reservoir outflow (site 15). An aqueous selenium level even of $2 \mu \mathrm{g} / \mathrm{L}$ has the ability to bioaccumulate in the food chain and cause reproductive failure in fish and wildlife (Lemly, 1993). Other studies have found selenium to bioaccumulate in the food chain with levels between 2 and $16 \mu \mathrm{g} / \mathrm{L}$ (Woock, 1984; Lemly, 1985; Gillespe and Baumann, 1986). Bioaccumulation of selenium, from surrounding water or sediments, into dietary tissues has been shown to be a greater threat than waterborne selenium concentrations alone (Ogle and Knight, 1989; Lemly, 1993; Hamilton, 2004).

\section{Sediments}

The selenium concentrations from the stream sediment samples were not statistically different between mined and unmined sites. This is typical in shallow lotic systems, like Mud River. Selenium remains in the water column as either selenate or selenite until it is reduced and accumulated in sediments in slower moving waters, like a pool, reservoir, or wetland. Sediment selenium concentrations for the stream samples were all less than the $2 \mu \mathrm{g} / \mathrm{g}$ toxic effect threshold and therefore are considered to have no hazard (Lemly, 2002). The reservoir sampling locations, for the top $5 \mathrm{~cm}$, showed no significant difference among the transect sites. The average selenium concentrations at each sampling site on the reservoir were under or near the 2 $\mu \mathrm{g} / \mathrm{g}$ TET reported by Lemly (2002) indicating there is low hazard for bioaccumulation into the benthic food chain. A wetland study showed even more reduced selenium concentrations in the water $(0.9$ to $1.6 \mu \mathrm{g} / \mathrm{L})$ and sediment $(0.4$ to $1.4 \mu \mathrm{g} / \mathrm{g})$ produced elevated levels $(8.1$ to $10.4 \mu \mathrm{g} / \mathrm{g})$ in chironomid larvae (Zhang and Moore, 1996). Both Lemly (2002) and Zhang and Moore (1996) had water and sediment selenium levels below those seen in the Mud River Watershed 
and these systems had invertebrates with whole body concentrations above the dietary threshold for fish and other aquatic life. Overall, low levels of selenium in the sediments in Mud River may be able to accumulate in the aquatic food chain by benthic macroinvertebrates, or can enter by assimilation in primary producers (e.g. plankton and periphyton).

\section{Plankton}

Selenium concentrations for primary producers differed significantly between Upper Mud River Reservoir sites and the reference. The Mud River Reservoir sites did not differ from each other. Lack of significant difference could be attributed to plankton drift within the reservoir, or sampling proximity. Mud River Reservoir site 2 was located near the dam, where the two main stems (Left Fork and Mud River) confluence. Under normal flows, high selenium waters from Mud River might be able to flow, even if for a short distance, into the Left Fork areas allowing for selenium accumulation in plankton. For this study, planktonic species were not sorted into phytoplankton, bacterioplankton, or zooplankton. However, Debruyn and Chapman (2007) have shown that for plankton communities short term up-take rates of selenite are higher than selenate. Also, bacterioplankton and phytoplankton are major contributors to the biogeochemical cycle of selenium since they are the first step in selenium accumulation in the food chain. For zooplankton, dietary uptake of selenium is a more dominate pathway of assimilation than from waterborne intake (Debruyn and Chapman, 2007). Sublethal toxic effects for the organism have been recorded in laboratory studies at whole body concentrations of 1-30 $\mu \mathrm{g} / \mathrm{g}$ DW (Debruyn and Chapman, 2007). Debruyn and Chapman (2007) found that adverse effects to the organism based on whole body concentrations are taxa dependent. In Daphnia, reduced weight was seen at whole body concentrations of $20 \mu \mathrm{g} / \mathrm{g} \mathrm{DW}$ and reproductive failure at $30 \mu \mathrm{g} / \mathrm{g} \mathrm{DW}$ (Ingersoll et al., 1990). Foe and Knight (1986) showed reduced cell replication 
in green algae when selenium whole body concentrations reached $20 \mu \mathrm{g} / \mathrm{g}$. Another study by Kiffney and Knight (1990) showed reduced chlorophyll-a in cyanobacterium when whole body levels reached an extreme concentration (394-700 $\mu \mathrm{g} / \mathrm{g})$. Plankton collected from Upper Mud River Reservoir site 1 and site 2 fell below the adverse effect levels shown in Daphnia, but were still higher than the purposed dietary threshold $(3 \mu \mathrm{g} / \mathrm{g} \mathrm{DW})$ for consumption by other aquatic organisms (Lemly, 2002).

Selenium water concentrations are not always good indicators of selenium whole body concentrations within primary producers. Debruyn and Chapman (2007) showed that zoobenthos and algae concentrations were 2-3 times higher than surrounding water column selenium levels indicating that water quality tends to underestimate the range of selenium toxicity and in fact they were very poorly correlated. They also found that plankton whole body concentrations did not mimic decreasing water column selenium concentrations, resulting in elevated levels compared to water concentrations, allowing for selenium to persist in the food chain even as aqueous selenium decreases. For Mud River Reservoir, the average selenium levels in water samples are similar to those found in plankton, with the plankton levels being slightly higher.

\section{Benthic macroinvertebrates}

Whole body selenium levels in benthic macroinvertebrates in Upper Mud River watershed, regardless of functional feeding group, were higher in mined areas when compared to unmined areas within the watershed and the reference site. Average macroinvertebrate selenium levels from mined sites $(10.4 \pm 0.691 \mu \mathrm{g} / \mathrm{g}$ DW $)$ were lower than whole body macroinvertebrate concentrations from other studies (19-102 $\mu \mathrm{g} / \mathrm{g}$ DW) in which a reduction in abundance or 
community structure has not been documented (Schuler et al., 1990; Orr et al., 2006; Debruyn and Chapman, 2007). For example, an acute toxicity test with Hyalella (Amphipoda) and Nephelopsis (Hirundinea) showed selenium induced LC50's occurring at water concentrations of $400 \mu \mathrm{g} / \mathrm{L}$ and 400,000 $\mu \mathrm{g} / \mathrm{L}$, respectively (Debruyn and Chapman, 2007).

There is a hierarchy of selenium accumulation between functional feeding groups in a community indicating the importance of the benthic food chain to the cycling of selenium. Based on a study by Muscatello at al. (2008), selenium whole body concentrations in filterer invertebrates were similar to plankton, while detritivore and predator invertebrates have a higher concentration. Regardless of functional feeding group, invertebrates are able to accumulate high doses of selenium that is passed on in the food chain even when water concentrations are low, suggesting dietary uptake can dominate toxicity (Debruyn and Chapman, 2007). There are numerous field and laboratory studies that indicate selenium transfer, and subsequent adverse effects to fishes and aquatic wildlife is highly dependent on dietary concentrations (Woock et al., 1987; Heinz et al., 1989; Lemly, 1993; Hamilton, 2003). Benthic macroinvertebrates from mined portions of Mud River exceeded the toxic effect threshold for dietary selenium ( $3 \mu \mathrm{g} / \mathrm{g}$ DW) transfer to fish and aquatic birds (7 $\mu \mathrm{g} / \mathrm{g}$ DW) (Lemly 1993, 2002).

Typically, mined areas with high levels of selenium in the water have more selenium deposited in the sediments which can result in high levels of whole body selenium in the benthic macroinvertebrates associated with them (Muscatello et al., 2008). Selenium becomes incorporated into a benthic organism's body when it sifts through sediments to obtain food, or build cases, and ingests the adsorbed selenium from the sediments or other food source. Sediment levels in the Mud River watershed fell below the toxic effect threshold, in fact the levels were of no to minimal risk for bioaccumulation in the food chain. However, the 
periphyton and other forms of dietary organic matter, such as leaves and woody debris, were not tested for selenium concentrations so it cannot be determined if waterborne or dietary selenium are responsible for the elevated levels seen in benthic macroinvertebrates. Regardless of the pathway that selenium enters benthic macroinvertebrates, there is still evidence of bioaccumulation and magnification between the functional feeding groups with predators being consistently higher in whole body selenium concentrations.

\section{Bluegill Tissues}

The elevated aqueous and dietary selenium levels throughout Mud River Reservoir have produced elevated whole body and gonad concentrations in adult bluegill. The average selenium concentrations in both whole body and gonad tissues from Upper Mud River Reservoir were significantly higher than the reference site. The proposed toxic effect threshold signifies that there is food chain bioaccumulation with potential dietary toxicity and reproductive impairment to the bluegill population. Lemly $(2002,1995)$ did not provide hazard categories for whole body concentrations. However, Lemly $(2002,1995)$ provided the toxicity profile for reproductive impairment which is based on fish egg selenium concentrations. The calculated mean fish egg concentration for the Upper Mud River Reservoir bluegill $(68.76 \pm 1.95 \mu \mathrm{g} / \mathrm{g} \mathrm{DW})$ falls into the high hazard category for selenium induced reproductive impairment (>20 $\mu \mathrm{g} / \mathrm{g} \mathrm{DW}$ ) (Lemly 1995, 2002).

Selenium concentrations above the toxic effect threshold for whole body have been shown to affect growth and reproduction, and cause tissue damage in organs or mortality. Mortality in Chinook salmon (Oncorhynchus tshawytscha) was documented when whole body levels exceeded $10 \mu \mathrm{g} / \mathrm{g}$ DW with impaired growth at a much lower level $(2-3 \mu \mathrm{g} / \mathrm{g} \mathrm{DW})$ 
(Hamilton and Windmeyer, 1990). Fathead minnows (Pimephales promelas) also exhibited inhibited growth at levels slightly higher selenium levels (6-8 $\mu \mathrm{g} / \mathrm{g}$ DW) than Chinook salmon (Ogle and Knight, 1989) with reproductive failure at elevated ovary concentrations ( $24 \mu \mathrm{g} / \mathrm{g}$ DW) (Schultz and Hermanutz, 1990). Red shiners (Cyprinella lutrensis), with elevated whole body selenium concentrations were collected from Belews Lake, North Carolina. These individuals were the primary diet of striped bass during a laboratory experiment which showed mortality of the striped bass within 78 days (Coughlan and Velte, 1989). Lemly $(1985,2002)$ documented developmental deformities in Belews Lake, NC from fish with whole body concentrations of $15 \mu \mathrm{g} / \mathrm{g}$ which was suggested to be responsible for the elimination of 9 centrachid species from the lake. Other studies have shown reduced survival in bluegill larvae at adult whole body concentrations below the average whole body selenium level seen in Upper Mud River Reservoir (Coyle et al., 1993).

The condition factors in the Upper Mud River Reservoir bluegill population were significantly lower than the reference bluegill population. However, condition can be affected by fish density, reduced food availability and can fluctuate with seasons, sexual maturation, and geographic location which may be a reason why the relative weights were not statistically different (Lohner et al., 2001). Fulton condition factors have a length bias associated with them in that if the slope of the populations is not equal to 3.0 then the population with the lower mean length will also have the lower condition factor (Cone, 1989).

Selenium concentrations in bluegill gonads were consistently higher than the whole body concentrations measured which is consistent with other studies. Ogle and Knight (1989) found that female fathead minnows fed a range of selenium laden diets ( 0.5 to $160 \mu \mathrm{g} / \mathrm{g} \mathrm{DW})$, along with waterborne levels ( 0 to $30 \mu \mathrm{g} / \mathrm{L}$ ), had ovary concentrations higher than other body tissues. 
However, they did not see any reproductive impairments with ovary concentrations ranging from 6.0 to $10.9 \mu \mathrm{g} / \mathrm{g}$ DW. Schultz and Hermanutz (1990) dosed experimental streams with sodium selenite $(10 \mu \mathrm{g} / \mathrm{L})$ which contained fathead minnows. The fish reared in this stream were able to spawn and embryos were sampled and hatched. Embryos had a higher instance of edema and lordosis with elevated ovary concentrations $(5.89 \mu \mathrm{g} / \mathrm{g}$ wet weight $)$ and fry survival to swim-up was impaired at levels of $15 \mu \mathrm{g} / \mathrm{g}$ (Schultz and Hermanutz, 1990). Reproductive failure in nine centrarchid species occurred at ovary concentrations of 40 to $60 \mu \mathrm{g} / \mathrm{g}$ from Belews Lake, $\mathrm{NC}$ (Cumbie and Van Horn, 1978; Lemly, 1985). Moreover, Gillespie and Baumann (1986) crossed contaminated bluegill females with uncontaminated males, which showed that the elevated ovary selenium concentrations (12 to $55 \mu \mathrm{g} / \mathrm{g}$ ) resulted in higher instances of deformities and death. They also found that the elevated selenium levels did not affect fertility or hatchability of the eggs, but the transfer from yolk-sac to larvae produced higher whole body selenium in the fry (Gillespie and Baumann, 1986). The gonad selenium concentrations seen in Mud River Reservoir were above those seen in fathead minnow study and similar to bluegill female study to cause impairment to progeny and affect overall reproductive success (Gillespie and Baumann, 1986).

Bluegill larval laboratory study

Based on the adult tissue concentrations and the calculated egg concentrations of selenium, reproductive impairment would be expected in the Upper Mud River Reservoir bluegill population. However, due to water quality related issues with the egg and larval experiment in this study, no conclusion about larval health and survival can be made. During the experiments, ammonia levels became elevated and likely led to mortality. There are no studies that relate bluegill larval mortality to specific ammonia concentrations. However, fathead 
minnow larvae and embryos showed a decrease in survival and normal larvae at hatch at ammonia concentrations of $0.26 \mathrm{mg} / \mathrm{L}$ (Mayes et al., 1986). The larval bluegill and embryos were subjected to average ammonia concentrations of $0.31 \pm 0.04$ (MRR A), $0.766 \pm 0.059$ (Ref A), $0.178 \pm 0.023$ (MRR B), and $0.133 \pm 0.018$ (Ref B), all of which fell above or near the chronic levels for fathead minnow larvae/embryos. The increased ammonia levels observed in our study were the product of decomposing organic matter in which eggs were attached, residual powdered fish food, and any unhatched eggs present. In order to combat elevated ammonia levels, multiple full water changes were completed daily. A flow through or filtration system would be an effective way to ensure reduced ammonia levels. Since water from each study site was being used to rear the larval fish, a flow through system could not be used at our facility.

Hatching and survival is also dependent on temperature (Mischke and Morris, 1997). The optimal temperature for hatching and growth of bluegill eggs is $25^{\circ} \mathrm{C}$ in which eggs can hatch within 2 days of fertilization and reach swim-up within 3 days of hatching (Bryan et al., 1994; Mischke and Morris, 1997). Bluegill embryos and larvae from Mud River Reservoir and the reference site were subjected to temperatures between $21-22{ }^{\circ} \mathrm{C}$. Temperatures at collection sites were above $27^{\circ} \mathrm{C}$ and it is unclear what effects the drop in temperature had on developing embryos. Water temperatures were kept consistent by increasing room temperature to $27-29^{\circ} \mathrm{C}$. Despite water quality issues, about an $8 \%$ survival was still observed in the reference B tanks.

\section{Summary}

Water and benthic macroinvertebrate selenium concentrations from the Upper Mud River Watershed are classified as high hazard for impairment to fish health and bioaccumulation within the food chain. The high dietary level of the macroinvertebrates poses a high risk for toxicity to 
fish and other wildlife (Schultz and Hermanutz, 1990). However, the sediment selenium concentrations in the Upper Mud River Watershed show no hazard for accumulation meaning the selenium could be staying within the water column and being passed through the food chain via another route (Lemly, 2002). Consequently, the bluegill population living in the Upper Mud River Reservoir has high whole body and gonad concentrations of which poses high hazard for reproductive impairment (Lemly, 2002). There were no deformities seen in bluegill larvae or juvenile fish during this study, but our samples sizes were small compared to surveys that reported 10 to 13\% deformities in larval bluegill (Ben Lowman, Personal Communication). Also, due to elevated levels of ammonia and reduced temperatures in our larval study, survival was low and conclusions cannot be made. 


\section{Literature Cited}

Avila, V. L. 1975. A field study of nesting behavior of male bluegill sunfish (Lepomis macrochirus Rafinesque). The American Midland Naturalist. 96:195-207.

Beard, T. 1982. Population dynamics of young-of-the-year bluegill. Wisconsin Department of Natural Resources Technical Bulletin No. 127.

Becker, G. C. 1983. Bluegill. Pages 844-851 In Fishes of Wisconsin. University of Wisconsin Press. Madison Wisconsin.

Bowie, G.L., J.G. Sanders, G.F. Riedel, C.C. Gilmour, D.L. Breitburg, G.A. Cutter, and D.B. Porcella, 1996. Assessing selenium cycling and accumulation in aquatic ecosystems. Water, Air, and Soil Pollution. 90:93-104.

Brix, K. V., J. S. Volosin, W. J. Adams, R. J. Reash, R. C. Carlton, and D. O. McIntyre. 2001. Effects of sulfate on the acute toxicity of selenate to freshwater organisms. Environmental Toxicology and Chemistry. 5: 1037-1045.

Bryan, M., J. Morris, and G. Atchison. 1994. Methods for culturing bluegill in the laboratory. The Progressive Fish Culturist. 56:217-221.

Canton, S. P. and W. D. Van Derveer. 1997. Selenium toxicity to aquatic life: An argument for sedimentbased water quality criteria. Environmental Toxicology and Chemistry. 16:1255-1259.

Cone, R. S. 1989. The need to reconsider the use of condition indices in fishery science. Transactions of the American Fisheries Society. 118:510-514.

Coughlan, D. J. and J. S. Velte. 1989. Dietary toxicity of selenium-contaminated red shiners to striped bass. Transactions of the American Fisheries Society. 118:400-408.

Coyle, J., D. Buckler and C. Ingersoll. 1993. Effect of dietary selenium on the reproductive success of bluegills (Lepomis macrochirus). Environmental Toxicology and Chemistry. 12:551-565.

Cumbie, P.M. and S. L. Van Horn. 1978. Selenium accumulation associated with fish mortality and reproductive failure. Proceedings of the Annual Conference of the Southeastern Association of Fish and Wildlife Agencies. 32:612-624.

Debruyn, A.M.H. and P.M. Chapman. 2007. Selenium toxicity to invertebrates: Will proposed thresholds for toxicity to fish and birds also protect their prey? Environmental Science and Technology. 41:17661770.

Ellis, M. M., H. L. Motley, M. D. Ellis, and R. O. Jones. 1937. Selenium poisioning in fishes. Proceedings of the Society for Experimental Biology and Medicine. 36: 519-522.

Foe, C. G., and A.W. Knight. 1986. Selenium bioaccumulation, regulation, and toxicity in the green alga, Selenastrum capricornutum and dietary toxicity of the contaminated alga to Daphnia magna. Slocum D (ed). Selenium in the Environment. CA Ag Institute Pub \#CAT1/860201. California Agricultural Technology Institute, CA. St. Univ, Fresno, CA. pp 77-88. 
Gillespie, R.B. and P. C. Baumann. 1986. Effects of high tissue concentrations of selenium on reproduction of bluegills. Tranactions of American Fisheries Society. 115:208-213.

Gross, M. R., and A. M. MacMillan. 1981. Predation and the evolution of colonial nesting in bluegill sunfish (Lepomis macrochirus). Behavioral Ecology and Sociobiology. 8:163-174.

Hamilton, S. J., and R. H. Wiedmeyer. 1990. Concentrations of boron, molybdenum, and selenium in Chinook salmon. Transactions of the American Fisheries Society. 119: 500-510.

Hamilton, S.J. 2003. Review of residue-based selenium toxicity thresholds for freshwater fish. Ecotoxicology and Environmental Safety. 56:201-210.

Hamilton, S.J. 2004. Review of selenium toxicity in the aquatic food chain. Science of the Total Environment. 326:1-31.

Hamre, K., T. A. Mollan, O. Saele, and B. Erstad. 2008. Rotifers enriched with iodine and selenium increase survival in Atlantic cod (Gadus morhua) larvae. Aquaculture. 284: 190-195.

Hansen, L. D., K. J. Maier, and A. W. Knight. 1993. The effect of sulfate on the bioconcentrations of selenate by Chironomus decorus and Daphnia magna. Archives of Environmental Contamination and Toxicology. 25:72-78.

Heinz, G. H., D. J. Hoffman, A. J. Krynitsky, and D. M. D. Weller. 1989. Impaired reproduction of mallards fed an organic form of selenium. Journal of Wildlife Management. 53: 418-428.

Ingersoll, C. G., F. J. Dwyer, and T. W. May. 1990. Toxicity of inorganic and organic selenium to Daphnia magna (Cladocera) and Chironomus riparius (Diptera). Environmental Toxicology and Chemistry. 27:441-448.

Kiffney, P. and A. W. Knight. 1990. The toxicity and bioconcentrations of selenate, selenite, and selenomethionine by the alga, Anabaena flos-aquas. Archives of Environmental Contamination and Toxicology. 19:488-494.

Lemly, A. D. 1985. Toxicology of selenium in a freshwater reservoir: Implications for environmental hazard evaluation and safety. Ecotoxicology and Environmental Safety. 10:314-338.

Lemly, A. D., and G. J. Smith. 1987. Aquatic cycling of selenium-Implications for fish and wildlife. U.S. Fish and Wildlife Service leaflet 12, 10p.

Lemly, A.D. 1993. Guidelines for evaluating selenium data from aquatic monitoring and assessment studies. Environmental Monitoring and Assessment. 28:83-100.

Lemly, A. D. 1995. A protocol for aquatic hazard assessment of selenium. Ecotoxicology and Environmental Safety. 32:280-288.

Lemly, A.D. 1997. A teratogenic deformity index for evaluating impacts of selenium on fish populations. Ecotoxicology and Environmental Safety. 37:259-266. 
Lemly, A. D. 1999. Selenium impacts on fish: an insidious time bomb. Human and Ecological Risk Assessment. 5: 1139-1151.

Lemly, A.D. 2002. Symptoms and implications of selenium toxicity in fish: the Belews Lake case example. Aquatic Toxicology. 57:39-49.

Lohner, T. W., R. J. Reash, V. E. Willet, and L. A. Rose. 2001. Assessment of tolerant sunfish populations (Lepomis sp.) inhabiting selenium-laden coal ash effluents. Ecotoxicology and Environmental Safety. 50:203-216.

Lorentzen, M., A. Maage, and K. Julshamm. 1998. Supplementing copper to a fish meal based diet fed to Atlantic salmon parr affects liver copper and selenium concentrations. Aquaculture Nutrition. 4:67-72.

May, T.W, J.F. Fairchild, J.D. Petty, M.J. Walther, J. Lucero, M. Delvuax, J. Manring, and M. Armbruster. 2008. Environmental Monitoring and Assessment. 137:213-232.

Mayes, M. M., H. C. Alexander, D. L. Hopkins, and P. B. Latvaitis. 1986. Acute and chronic toxicity of ammonia to freshwater fish: A site specific study. Environmental Toxicology and Chemistry. 5:437-442.

McCune, B. and J.B. Grace. 2002. Analysis of Ecological Communities. MjM Software Design, Gleneden Beach, Oregon.

Merovich, G. T., J. M. Stiles, J. T. Petty, P. F. Ziemkiewicz, and J. B. Fulton. 2007. Water chemistrybased classification of streams and implications for restoring mined Appalachian watersheds. Environmental Toxicology and Chemistry 26(7): 1361-1369.

Mischke, C. and J. Morris. 1997. Out-of-season spawning of sunfish Lepomis spp. in the laboratory. The Progressive Fish-Culturist 59:297-302.

Muscatello, J.R., A.M. Belknap, and D. M. Janz. 2008. Accumulation of selenium in aquatic systems downstream of a uranium mining operation in northern Saskatchewan, Canada. Environmental Pollution. $156: 387-393$

Muscatello, J.R. and D. M. Janz. 2009. Assessment of larval deformities and selenium accumulation in northern pike (Esox lucius) and the white sucker (Catostomus commersoni) exposed to metal mining effluent. Environmental Toxicology and Chemistry. 28:609-618.

Ogle, R.S. and A.W. Knight. Effects of elevated foodborne selenium on growth and reproduction of the fathead minnow (Pimephales promelas). Archives of Environmental Contamination and Toxicology. 18:795-803.

Orr, P. L., K. R. Guiguer, and C. K. Russel. 2006. Food chain transfer of selenium in lentic and lotic habitats of a western Canadian watershed. Ecotoxicology and Environmental Safety. 63:175-188.

R Development Team. 2010. R: A Language and Environment for Statistical Computing. R Foundation for Statistical Computing. Vienna, Austria. http://www.R-project.org. 
Rider, S.A, S.J. Davies, A.N. Jha, A.A. Fisher, J. Knight, and J.W. Sweetman. 2009. Supra-nutritional dietary intake of selenite and selenium yeast in normal and stressed rainbow trout (Oncorhynchus mykiss): Implications on selenium status and health responses. Aquaculture. 295:282-291.

Sanders, R. W. and C. C. Gilmour. 1994. Accumulation of selenium in a model freshwater microbial food web. Applied and Environmental Microbiology. 60:2677-2683.

Schuler, C. A., R. G. Anthony, and H. M. Ohlendorf. 1990. Selenium in wetlands and waterfowl foods at Kesterson Reservoir, California. Archives of Environmental Contamination and Toxicology. 19:845-853.

Schultz, R. and R. Hermanutz. 1990. Transfer of toxic concentrations of selenium from parent to progeny in the fathead minnow (Pimephales promelas). Bulletin of Environmental Contamination and Toxicology. 45:568-573Sorensen, E.M.B. and T. L. Bauer. 1984a. A correlation between selenium accumulation in sunfish and changes in condition factor and organ weight. Environmental Pollution. 34: 357-366.

Skorupa, J. P., S. P. Morman, and J. S. Sefchick-Edwards. 1996. Guidelines for interpreting selenium exposures of biota associated with nonmarine aquatic habitats. Sacramento, CA. U.S. Fish and Wildlife Service, Sacramento Field Office, Technical Report.

Smith, W. E. 1975. Breeding and culture of two sunfish, Lepomis cyanellus and L. megalotis, in the laboratory. The Progressive Fish-Culturist. 37:227-229.

Sorensen, E. M. B., P. M. Cumbie, T. L. Bauer, H. S. Bell, and C. W. Harlan. 1984. Histopathological, hematological, condition-factor, and organ-weight changes associated with selenium accumulation in fish from Belews Lake, North Carolina. Archives of Environmental Contamination and Toxicology. 13:153162.

Toetz, D. W. 1966. The change from endogenous to exogenous sources of energy in bluegill sunfish larvae. Investigations of Indiana Lakes \& Streams. 7:115-146.

Wang, C. and R. T. Lovell. 1997. Response to Edwardsiella ictaluri challenge by channel catfish fed organic and inorganic sources of selenium. Journal of Aquatic Animal Health. 9:172-179.

Wege, G.J., and R. O. Anderson. 1978. Relative weight (Wr): a new index of condition for largemouth bass. Pages 79-91 in G. D. Novinger and J. G. Dillard, editors. New approaches to the management of small impoundments. American Fisheries Society, North Central Division, Special Publication 5, Bethesda, Maryland.

Woock, S. E., W. R. Garrett, W. E. Partin, and W. T. Bryson. 1987. Decreased survival and teratogenesis during laboratory selenium exposures to bluegill, Lepomis macrochirus. Bulletin of Environmental Contamination and Toxicology. 39:998-1005.

Zhang, Y. and J. N. Moore. 1996. Selenium fractionation and speciation in a wetland system. Environmental Science and Technology. 30:2613-2619. 
Table 1: Sampling site locations with site descriptions for Upper Mud River Watershed and Plum Orchard Lake. Site types include: $\mathrm{U}=$ unmined, $\mathrm{M}=$ mined, and $\mathrm{R}=$ reference. The sites were sampled for one or all of the following: $\mathrm{W}=$ Water quality, $\mathrm{S}=$ Sediments (Stream), and I=Benthic macroinvertebrates

\begin{tabular}{|c|c|c|c|}
\hline Site ID & Site type & Sampled & Site description \\
\hline MudR01 & $\mathrm{U}$ & WSI & Downstream of Bearcamp Branch \\
\hline MudR02 & $\mathrm{U}$ & WSI & Downstream of Huntingcamp Branch \\
\hline MudR03 & $\mathrm{U}$ & WSI & Downstream of Rushpatch Branch \\
\hline MudR04 & M & WSI & Downstream of Lukey Fork \\
\hline MudR05 & M & WSI & Upstream of Ballard Fork \\
\hline MudR06 & M & WSI & Upstream of Sugartree Branch \\
\hline MudR07 & M & WS & Downstream of Connelly Branch \\
\hline MudR08 & M & WSI & Downstream of Stonecoal Branch \\
\hline MudR09 & M & WSI & Downstream of Boar Branch \\
\hline MudR10 & M & WSI & Upstream of Reservoir \\
\hline MudR11 & M & $\mathrm{W}$ & Reservoir at boat ramp \\
\hline MudR12 & $\mathrm{U}$ & WSI & Downstream of Dogbone Branch \\
\hline MudR13 & $\mathrm{U}$ & WSI & Left Fork discharge to Reservoir \\
\hline MudR14 & $\mathrm{U}$ & WS & Reservoir at CR58 bridge \\
\hline MudR15 & M & WSI & Reservoir discharge \\
\hline MudR16 & M & $\mathrm{S}$ & Downstream of Reservoir at boat ramp \\
\hline MudR17 & M & S & Upstream of beach \\
\hline MudR18 & M & $S$ & At earthen dam \\
\hline MudR19 & $\mathrm{U}$ & S & Downstream of MudR14 \\
\hline Ballard Fork & M & $\mathrm{W}$ & Ballard Fork \\
\hline Berry Branch & M & $\mathrm{W}$ & Berry Branch \\
\hline Stanley Fork & M & $\mathrm{W}$ & Stanley Fork \\
\hline Sugartree Branch & M & $\mathrm{W}$ & Sugartree Branch \\
\hline Upton Branch & $\mathrm{U}$ & W & Upton Branch \\
\hline POL01 & $\mathrm{R}$ & WI & Plum Orchard Lake boat docks \\
\hline POL02 & $\mathrm{R}$ & WI & Plum Orchard Lake boat ramp \\
\hline
\end{tabular}


Table 2: Results from principal component analysis (PCA) on water quality data from October 2008 to November 2010. The values given, also known as factor loadings, represent all the variables used to run a PCA. The variables that had loadings $\geq|0.4|$ were considered to significantly influence the principle component associated with it.

\begin{tabular}{lll}
\hline Variable & PC 1 & PC 2 \\
\hline Eigenvalue & 2.66 & 1.09 \\
\%Var Explained & 70.8 & 11.8 \\
Alkalinity $\left(\mathrm{mg} / \mathrm{L}\right.$ as $\left.\mathrm{CaCO}_{3}\right)$ & -0.978 & -0.041 \\
Hardness $\left(\mathrm{mg} / \mathrm{L}\right.$ as $\left.\mathrm{CaCO}_{3}\right)$ & -0.977 & -0.039 \\
Sulfate $(\mathrm{mg} / \mathrm{L})$ & -0.976 & -0.002 \\
Total Dissolved Solids $(\mathrm{mg} / \mathrm{L})$ & -0.925 & 0.188 \\
Total Selenium $(\mu \mathrm{g} / \mathrm{L})$ & -0.942 & 0.019 \\
Conductivity $(\mu \mathrm{s} / \mathrm{cm})$ & -0.934 & -0.079 \\
pH & -0.858 & -0.295 \\
Dissolved Iron $(\mathrm{mg} / \mathrm{L})$ & 0.888 & -0.305 \\
Total Organic Carbon $(\mathrm{mg} / \mathrm{L})$ & -0.269 & -0.305 \\
Total Iron $(\mathrm{mg} / \mathrm{L})$ & 0.029 & -0.929 \\
\hline
\end{tabular}


Table 3: Average water quality \pm standard error, for parameters measured once a month from October 2008 to November 2010 for mined and unmined portions of Upper Mud River Watershed and the reference site

\begin{tabular}{|c|c|c|c|}
\hline Variable & Mined & Unmined & Reference \\
\hline Temperature $\left({ }^{\circ} \mathrm{C}\right)$ & $14.19 \pm 0.42^{\mathrm{a}}$ & $13.60 \pm 0.57^{\mathrm{a}}$ & $17.83 \pm 1.45^{\mathrm{b}}$ \\
\hline Conductivity $(\mu \mathrm{s} / \mathrm{cm})$ & $1059.93 \pm 33.91^{\mathrm{a}}$ & $152.23 \pm 7.16^{\mathrm{b}}$ & $38.38 \pm 0.66^{\mathrm{c}}$ \\
\hline $\mathrm{pH}$ & $7.77 \pm 0.02^{\mathrm{a}}$ & $7.26 \pm 0.05^{\mathrm{b}}$ & $7.05 \pm 0.09^{b}$ \\
\hline $\mathrm{DO}(\mathrm{mg} / \mathrm{L})$ & $8.91 \pm 0.32^{\mathrm{a}}$ & $8.23 \pm 0.20^{\mathrm{a}}$ & $9.63 \pm 1.88^{\mathrm{a}}$ \\
\hline Hardness (mg/L as $\left.\mathrm{CaCO}_{3}\right)$ & $640.81 \pm 31.91^{\mathrm{a}}$ & $60.14 \pm 5.49^{b}$ & $13.35 \pm 0.302^{\mathrm{c}}$ \\
\hline Alkalinity $\left(\mathrm{mg} / \mathrm{L}\right.$ as $\left.\mathrm{CaCO}_{3}\right)$ & $159.45 \pm 5.54^{\mathrm{a}}$ & $37.09 \pm 2.05^{\mathrm{b}}$ & $16.87 \pm 1.37^{\mathrm{c}}$ \\
\hline $\mathrm{TDS}(\mathrm{mg} / \mathrm{L})$ & $1416.57 \pm 217.61^{\mathrm{a}}$ & $139.16 \pm 16.52^{b}$ & $16.87 \pm 1.37^{\mathrm{c}}$ \\
\hline Sulfate (mg/L) & $462.24 \pm 17.11^{\mathrm{a}}$ & $39.87 \pm 8.64^{b}$ & $12.14 \pm 0.64^{\mathrm{c}}$ \\
\hline Dissolved Iron (mg/L) & $0.068 \pm 0.007^{\mathrm{a}}$ & $0.131 \pm 0.009^{b}$ & $0.208 \pm 0.023^{\mathrm{c}}$ \\
\hline Total Iron (mg/L) & $0.606 \pm 0.189^{\mathrm{a}}$ & $0.566 \pm 0.093^{\mathrm{ab}}$ & $0.336 \pm 0.037^{\mathrm{b}}$ \\
\hline Total Selenium $(\mu \mathrm{g} / \mathrm{L})$ & $6.52 \pm 0.289^{\mathrm{a}}$ & $0.262 \pm 0.015^{\mathrm{b}}$ & $0.194 \pm 0.021^{\mathrm{b}}$ \\
\hline TOC (mg/L) & $3.46 \pm 0.36^{\mathrm{a}}$ & $3.22 \pm 0.308^{a}$ & $3.15 \pm 0.079^{\mathrm{a}}$ \\
\hline
\end{tabular}


Table 4: Average whole body selenium concentrations \pm standard error for each functional feeding group (Filterers, Gatherers, Scrapers, Predators, and Shredders) and composite sample for each site type (Unmined, Mined, and Reference). Sufficient mass for scrapers and filterers was not obtained from the reference site to run a selenium whole body analysis.

\begin{tabular}{lcccccc}
\hline \multicolumn{1}{c}{ Site } & Filterers & Gatherers & Scrapers & Shredders & Predators & Composite \\
\hline Unmined & $2.60 \pm 0.352^{\mathrm{a}}$ & $3.60 \pm 0.408^{\mathrm{a}}$ & $2.89 \pm 0.481^{\mathrm{a}}$ & $2.62 \pm 0.764^{\mathrm{a}}$ & $3.23 \pm 1.01^{\mathrm{a}}$ & $2.93 \pm 0.276^{\mathrm{a}}$ \\
Mined & $10.9 \pm 1.22^{\mathrm{b}}$ & $11.5 \pm 1.37^{\mathrm{b}}$ & $6.34 \pm 0.776^{\mathrm{b}}$ & $10.4 \pm 1.76^{\mathrm{b}}$ & $13.0 \pm 2.49^{\mathrm{b}}$ & $10.4 \pm 0.691^{\mathrm{b}}$ \\
Reference & & $2.98 \pm 0.606^{\mathrm{a}}$ & & $1.20 \pm 0.331^{\mathrm{a}}$ & $2.74 \pm 0.534^{\mathrm{a}}$ & $2.26 \pm 0.361^{\mathrm{a}}$ \\
\hline
\end{tabular}

${ }^{a}$ Same letter indicates no significant difference between site type. 
Table 5: Mean variables \pm standard error for bluegills sampled in the reference site and Mud River Reservoir. Mean egg selenium concentrations were calculated for each site from whole body concentrations.

\begin{tabular}{lcc}
\hline \multicolumn{1}{c}{ Variable } & Reference & Mud River Reservoir \\
\hline Weight $(\mathrm{g})$ & $27.05 \pm 3.07$ & $46.56 \pm 2.46$ \\
& $(\mathrm{n}=35)$ & $(\mathrm{n}=49)$ \\
Length $(\mathrm{mm})$ & $114.06 \pm 2.99$ & $144.98 \pm 2.16$ \\
& $(\mathrm{n}=35)$ & $(\mathrm{n}=49)$ \\
Cond. Factor $(\mathrm{K})^{\mathrm{a}}$ & $1.633 \pm 0.025^{*}$ & $1.465 \pm 0.017$ \\
& $(\mathrm{n}=35)$ & $(\mathrm{n}=49)$ \\
Relative Weight $(\mathrm{Wr})^{\mathrm{b}}$ & $100.16 \pm 0.96$ & $100.23 \pm 1.07$ \\
& $(\mathrm{n}=35)$ & $(\mathrm{n}=49)$ \\
Whole body Selenium $(\mu \mathrm{g} / \mathrm{g} \mathrm{DW})$ & $1.39 \pm 0.036^{*}$ & $20.84 \pm 0.59$ \\
& $(\mathrm{n}=86)$ & $(\mathrm{n}=118)$ \\
Gonad Selenium $(\mu \mathrm{g} / \mathrm{g} \mathrm{DW})$ & $2.50 \pm 0.532^{*}$ & $19.72 \pm 1.024$ \\
Egg Selenium $(\mu \mathrm{g} / \mathrm{g} \mathrm{DW})^{\mathrm{c}}$ & $(\mathrm{n}=10)$ & $(\mathrm{n}=31)$ \\
& $4.60 \pm 0.12^{*}$ & $68.76 \pm 1.95$ \\
\hline
\end{tabular}

*Significant difference $(\mathrm{p}<0.05)$ when compared with a Student's t-test.

${ }^{\text {a }}$ Condition factor $(\mathrm{K})$ calculated from the equation $\mathrm{K}=$ Weight $(\mathrm{g}) / \mathrm{Length}(\mathrm{mm})^{3} \times 10^{5}$.

${ }^{\mathrm{b}}$ Relative weight (Wr) was calculated from the linear relationship between length and weight following the methods of Wege and Anderson (1978).

${ }^{c}$ Egg selenium concentrations were calculated from whole body concentrations following the methods of Lemly and Smith (1987). 
Table 6: Mean water quality \pm standard error for the reference and Mud River Reservoir A and B tanks from the larval laboratory study. A tanks from the reference site were only compared with A tanks from Mud River Reservoir, and vice versa.

\begin{tabular}{|c|c|c|c|c|}
\hline \multirow{2}{*}{ Variable } & \multicolumn{2}{|c|}{ A Tanks } & \multicolumn{2}{|c|}{ B Tanks } \\
\hline & Reference & $\begin{array}{l}\text { Mud River } \\
\text { Reservoir }\end{array}$ & Reference & $\begin{array}{l}\text { Mud River } \\
\text { Reservoir }\end{array}$ \\
\hline Temperature $\left({ }^{\circ} \mathrm{C}\right)$ & $21.41 \pm 0.12^{*}$ & $22.69 \pm 0.12$ & $22.43 \pm 0.06^{* *}$ & $21.70 \pm 0.07$ \\
\hline Dissolved Oxygen (mg/L) & $7.87 \pm 0.09$ & $7.99 \pm 0.05$ & $7.24 \pm 0.12^{* *}$ & $8.07 \pm 0.08$ \\
\hline $\mathrm{pH}$ & $7.73 \pm 0.030^{*}$ & $8.36 \pm 0.008$ & $7.97 \pm 0.050^{* *}$ & $8.32 \pm 0.015$ \\
\hline Ammonia (mg/L) & $0.766 \pm 0.059 *$ & $0.308 \pm 0.041$ & $0.133 \pm 0.018$ & $0.178 \pm 0.023$ \\
\hline Nitrite (mg/L) & $0.010 \pm 0.001^{*}$ & $0.017 \pm 0.002$ & $0.010 \pm 0.004 * *$ & $0.028 \pm 0.006$ \\
\hline Hardness $\left(\mathrm{mg} / \mathrm{L}\right.$ as $\left.\mathrm{CaCO}_{3}\right)$ & $20.0 \pm 0.0^{*}$ & $250 \pm 0.0$ & $20.0 \pm 0.0 * *$ & $250 \pm 0.0$ \\
\hline Alkalinity $\left(\mathrm{mg} / \mathrm{L}\right.$ as $\left.\mathrm{CaCO}_{3}\right)$ & $16 \pm 1.13 *$ & $80 \pm 0.0$ & $10 \pm 0.0 * *$ & $80 \pm 0.0$ \\
\hline
\end{tabular}

*Significant difference between the Reference and Mud River Reservoir A tanks

**Significant difference between the Reference and Mud River Reservoir B tanks 


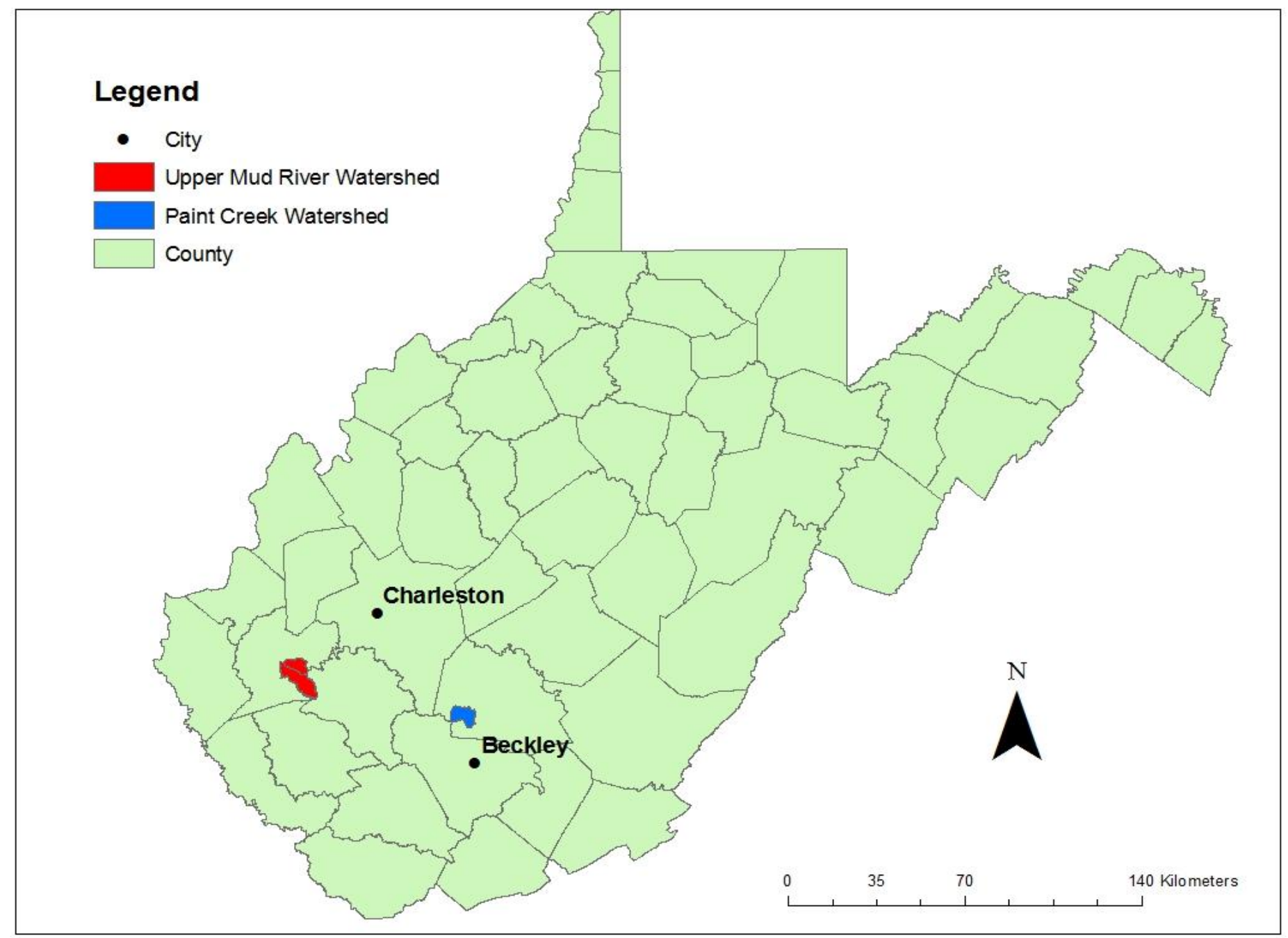

Figure 1: Locations of Upper Mud River and Paint Creek Watersheds in West Virginia. 


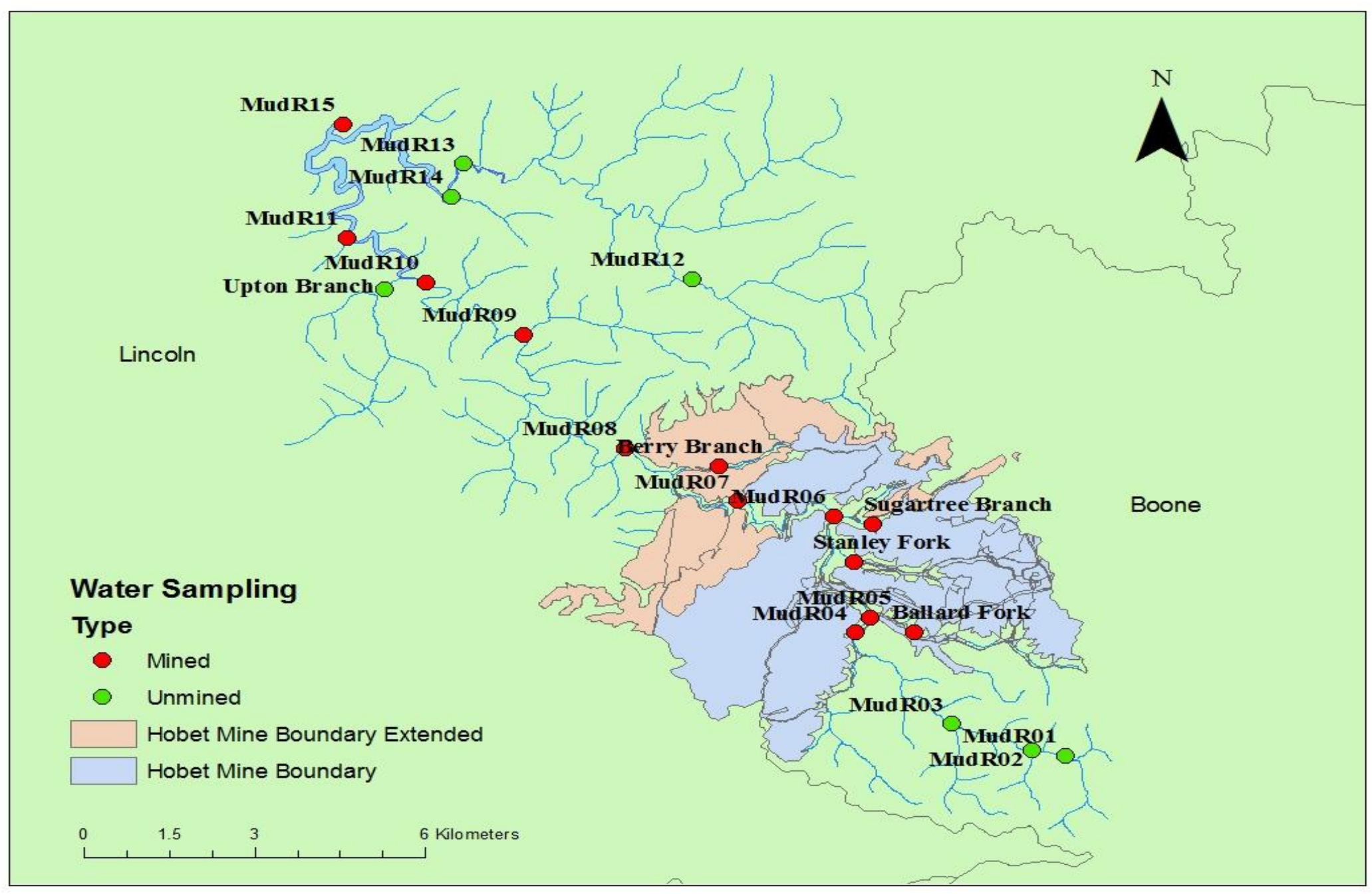

Figure 2: Water quality sampling locations within the Upper Mud River Watershed in Lincoln and Boone county. The Mined sites are any location within the Hobet 21 mine boundary and downstream while the unmined sites are located outside the mine boundary and on the Left Fork of Mud River. 


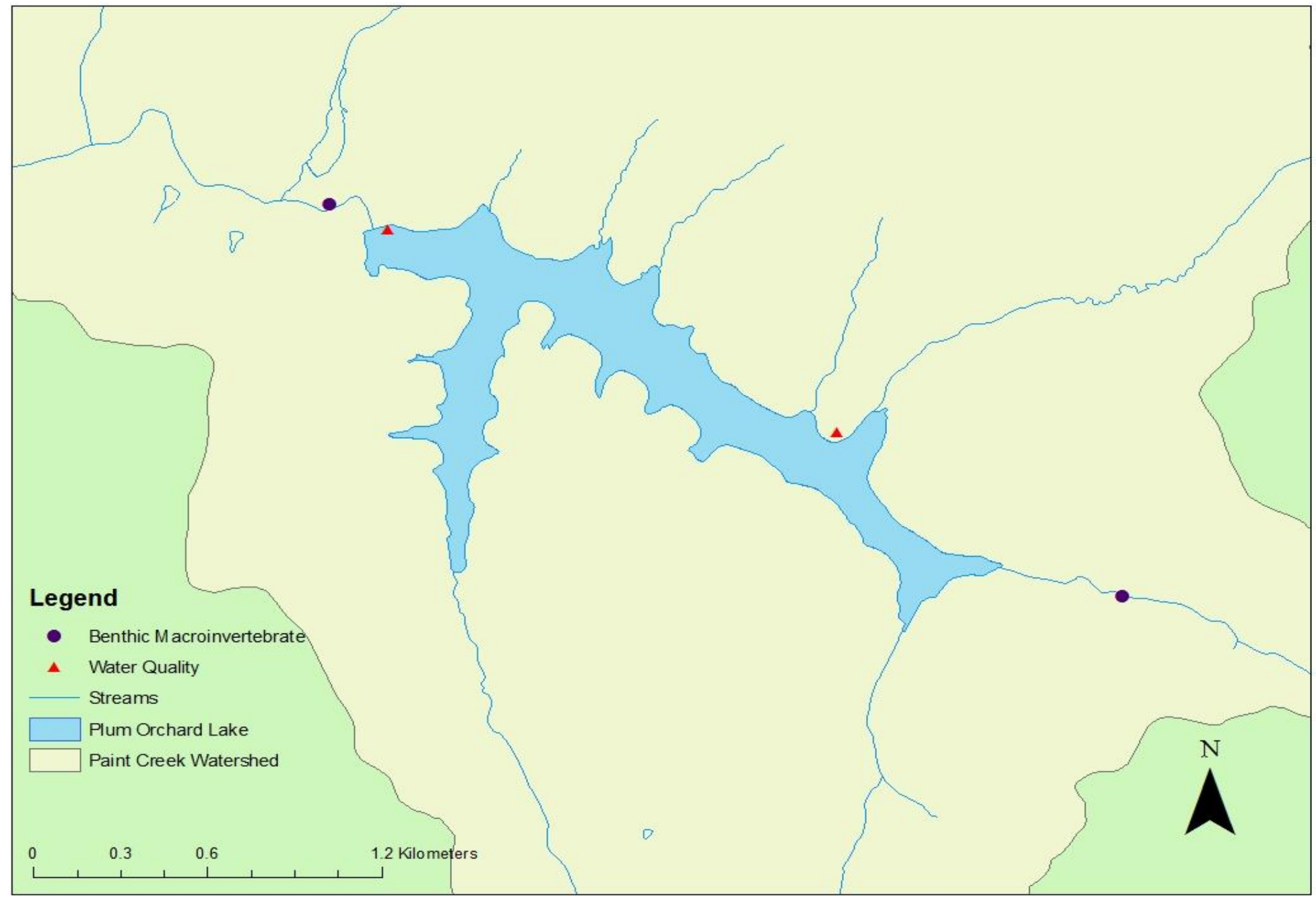

Figure 3: Water quality and benthic macroinvertebrate sampling locations within the reference site. 


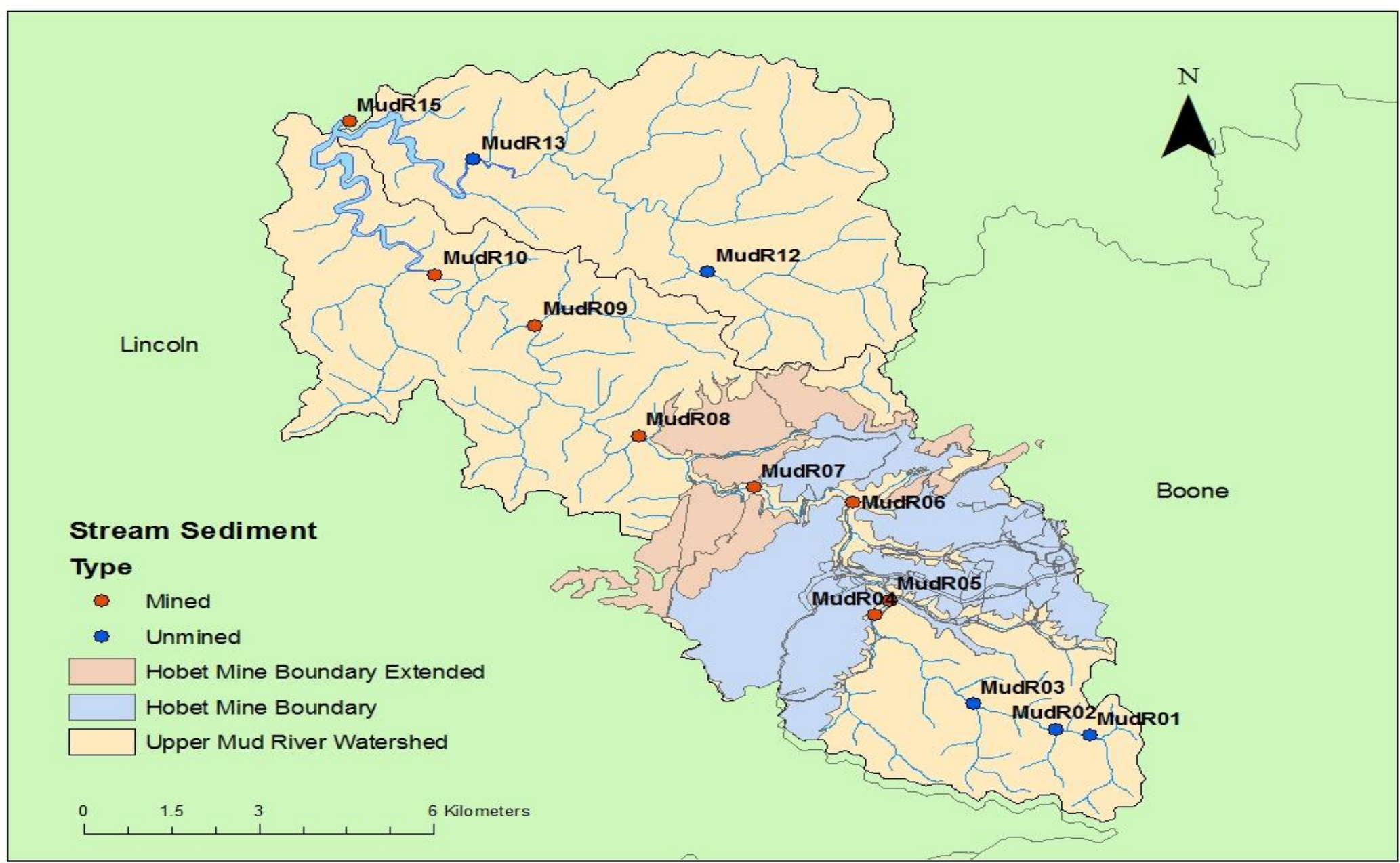

Figure 4: Stream sediment sampling sites correspond to water quality sites within Mud River Watershed. There are mined and unmined sites, at which samples the top $5 \mathrm{~cm}$ of the stream bed were collected and analyzed for selenium concentrations. 


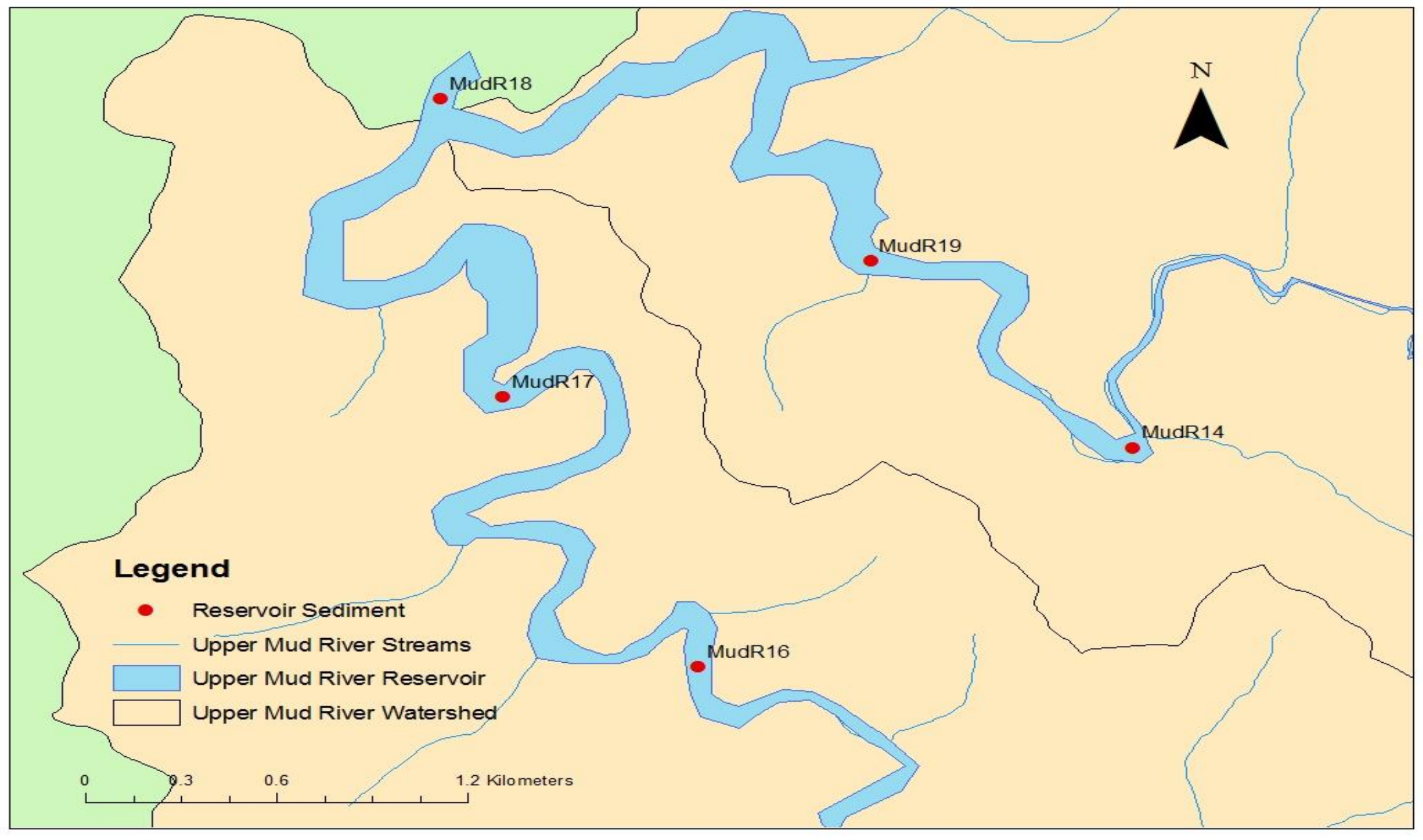

Figure 5: Reservoir sediment sampling transect locations with the Mud River Reservoir. Each transect had a left, middle, and right sampling location. At each location, a $5 \mathrm{~cm}$ sediment core was taken and at middle locations only a $20 \mathrm{~cm}$ core. Only the $5 \mathrm{~cm}$ samples were used in analysis. 


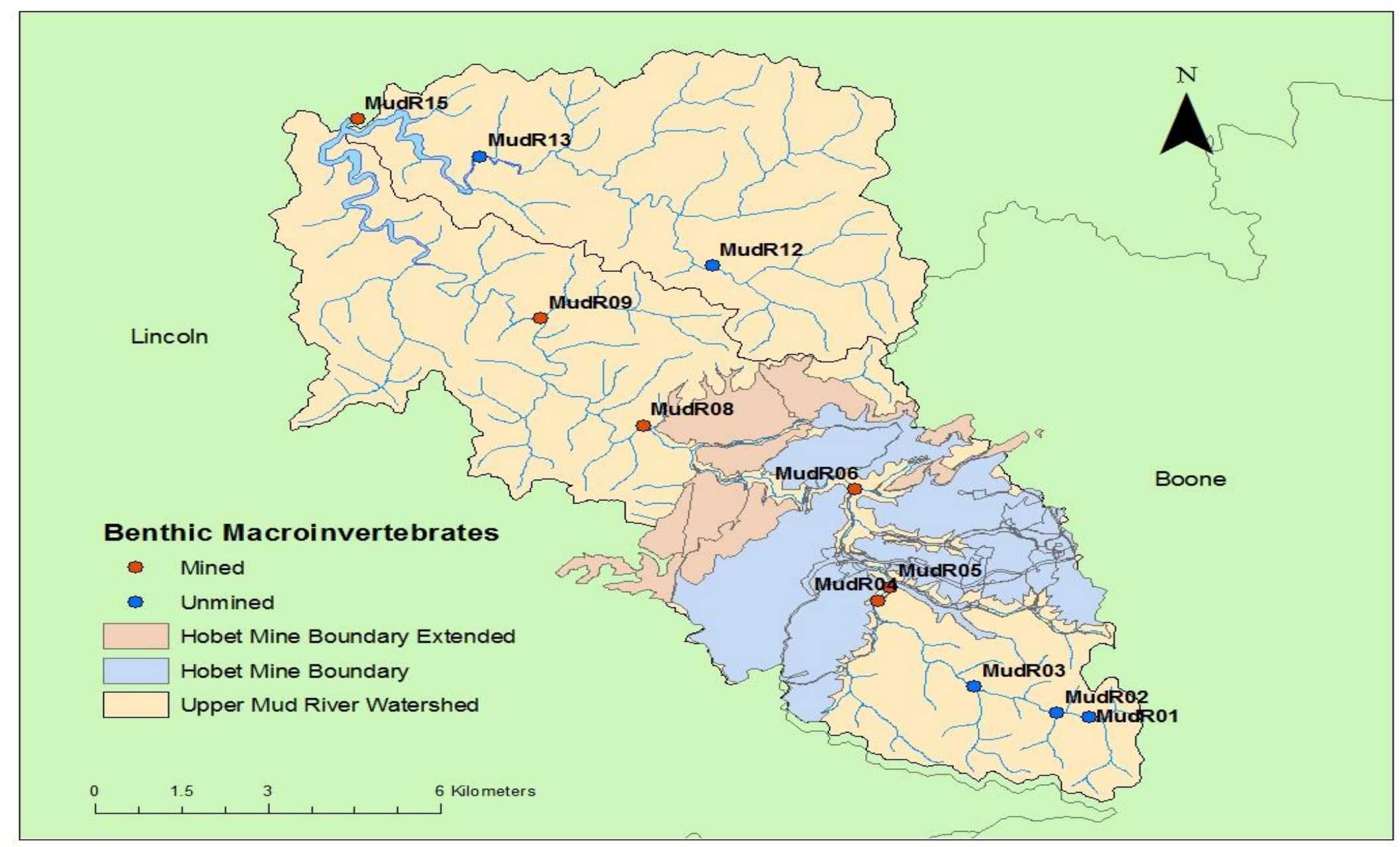

Figure 6: Benthic macroinvertebrate sampling locations within the Upper Mud River Watershed. The sampling locations correspond to water quality sites. Within the watershed, sites were split into mined or unmined groups based on the mine boundary. 


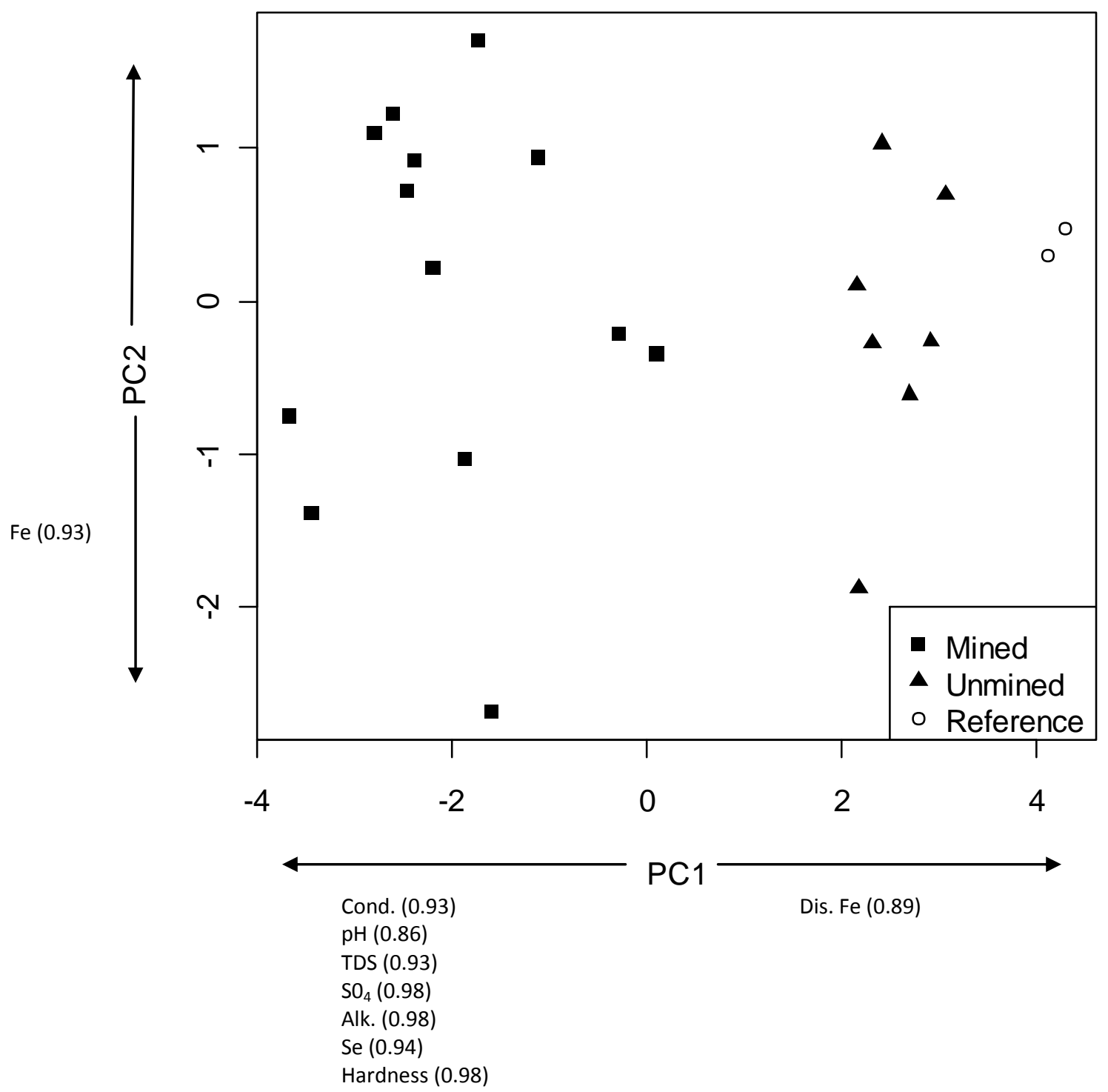

Figure 7: Scatter plot of the first two water chemistry principal components (PCs) with symbols representing site types. Variables significantly loading onto a given PC (loadings $\geq|0.4|$ ) are along each axis. Arrows indicate the direction of increase for each variable. Variables include conductivity (Cond.), $\mathrm{pH}$, alkalinity (Alk.), total dissolved solids (TDS), sulfate $\left(\mathrm{SO}_{4}\right)$, total selenium (Se), total iron (Fe), dissolved iron (Dis. Fe), and hardness. 


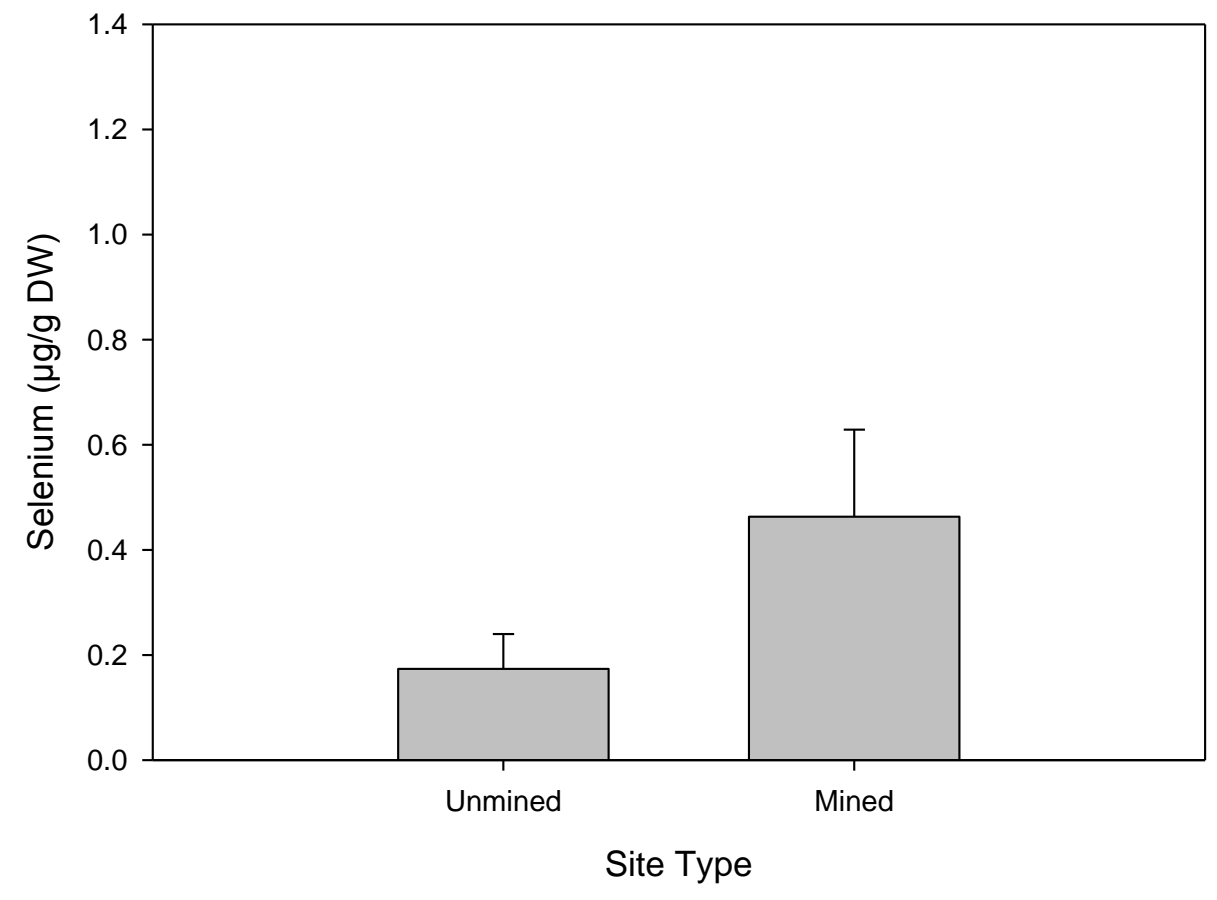

Figure 8: Mean stream sediment selenium concentrations \pm standard error for each site type analyzed with a Student's t-test. There was no significant difference in mean selenium concentrations between mined and unmined sites. 


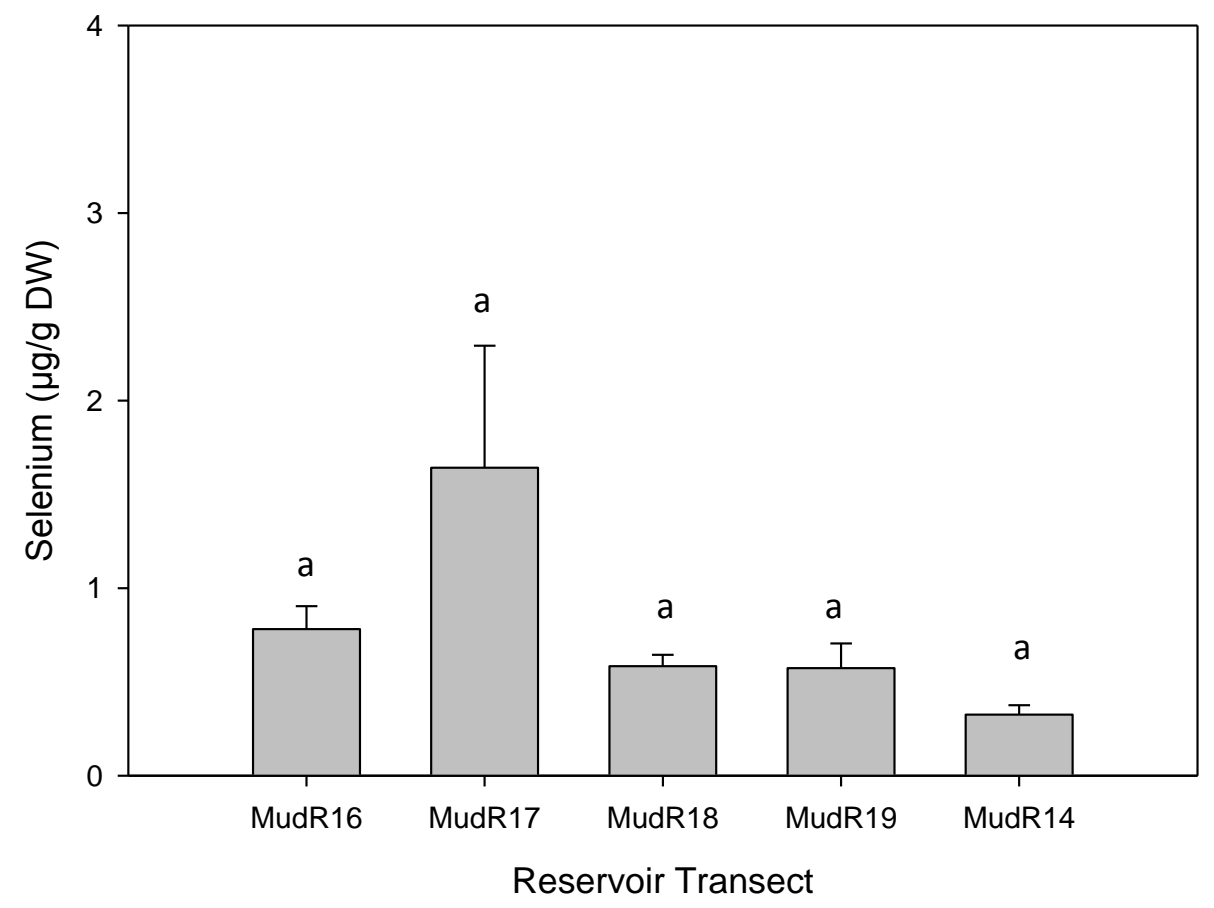

Figure 9: Mean reservoir transect sediment selenium concentrations \pm standard error for the top 5 $\mathrm{cm}$ analyzed with an ANOVA indicated that there was no statistical difference between the sediment selenium concentrations. 


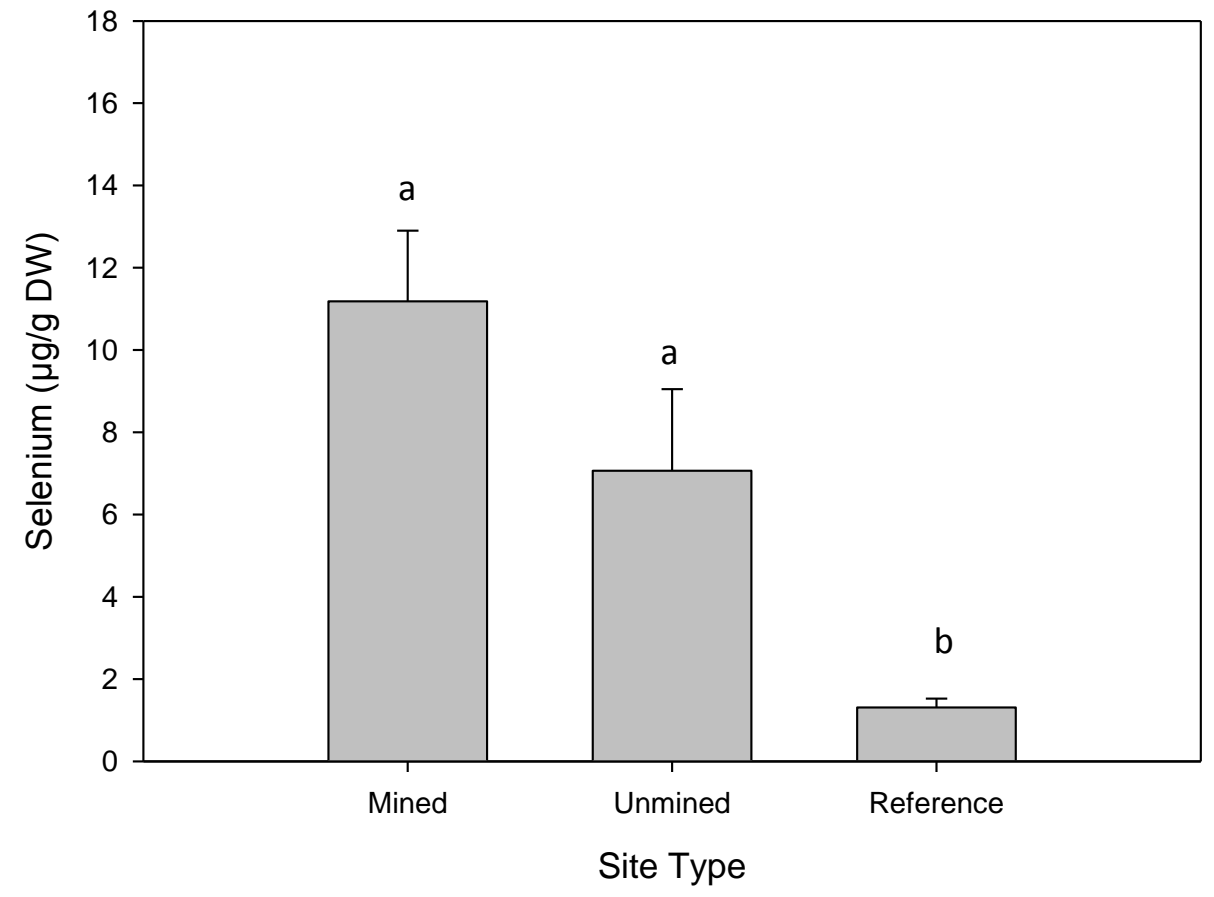

Figure 10: Plankton selenium concentrations ( $\mu \mathrm{g} / \mathrm{g} \mathrm{DW}$ ) at each site, regardless of depth (top and middle). Samples taken at each site over a 3 month sampling period were averaged and compared with an analysis of variance. The reference site was significantly different $(p<0.05)$ from both the mined and unmined Mud River Reservoir sites. However, the Mud River sites (mined and unmined) were not different from one another. 


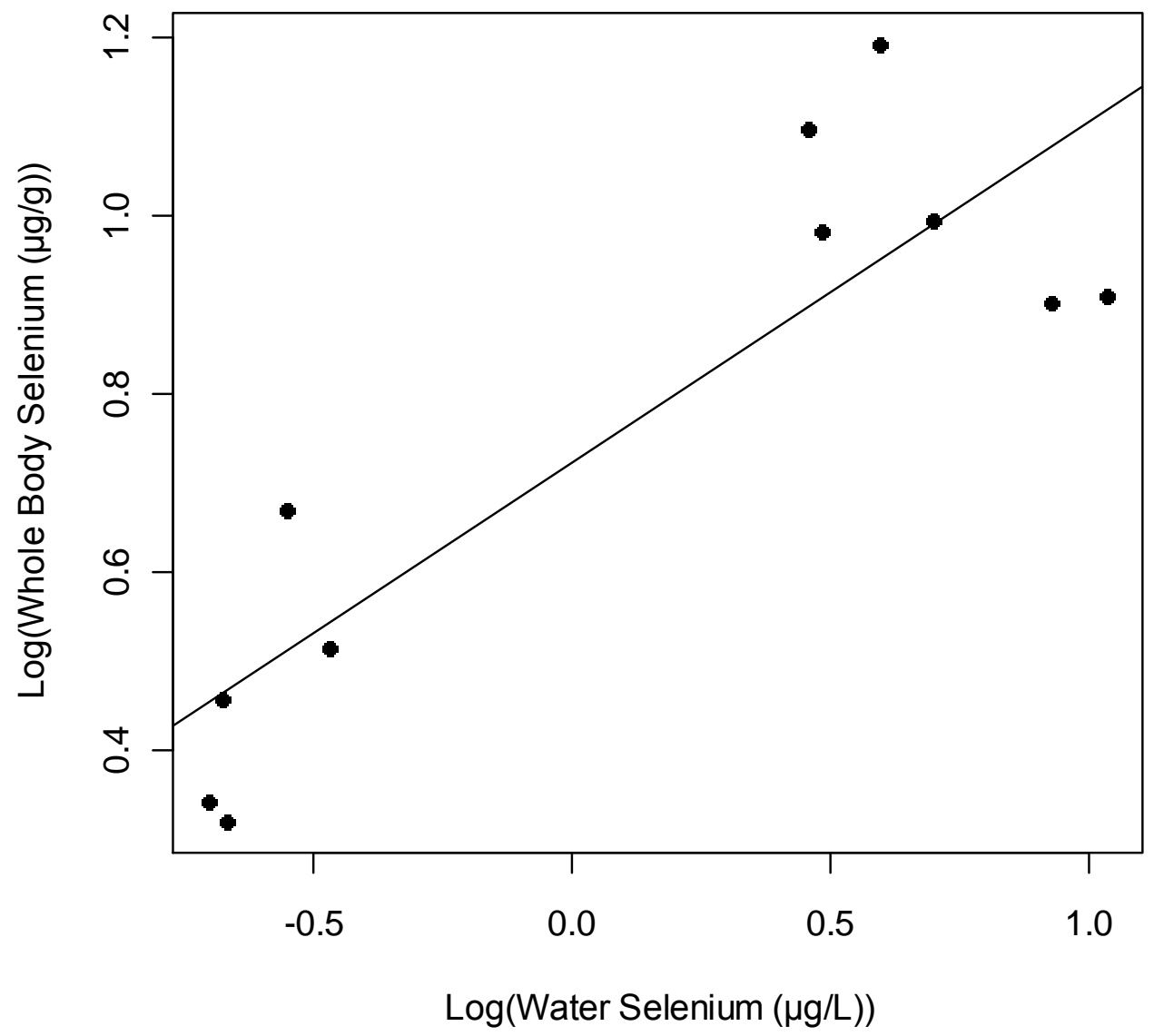

Figure 11: Linear regression of the relationship between the log of water selenium and the $\log$ of benthic whole body selenium concentrations. There was a strong correlation between the two variables $\left(r^{2}=0.77\right)$. 

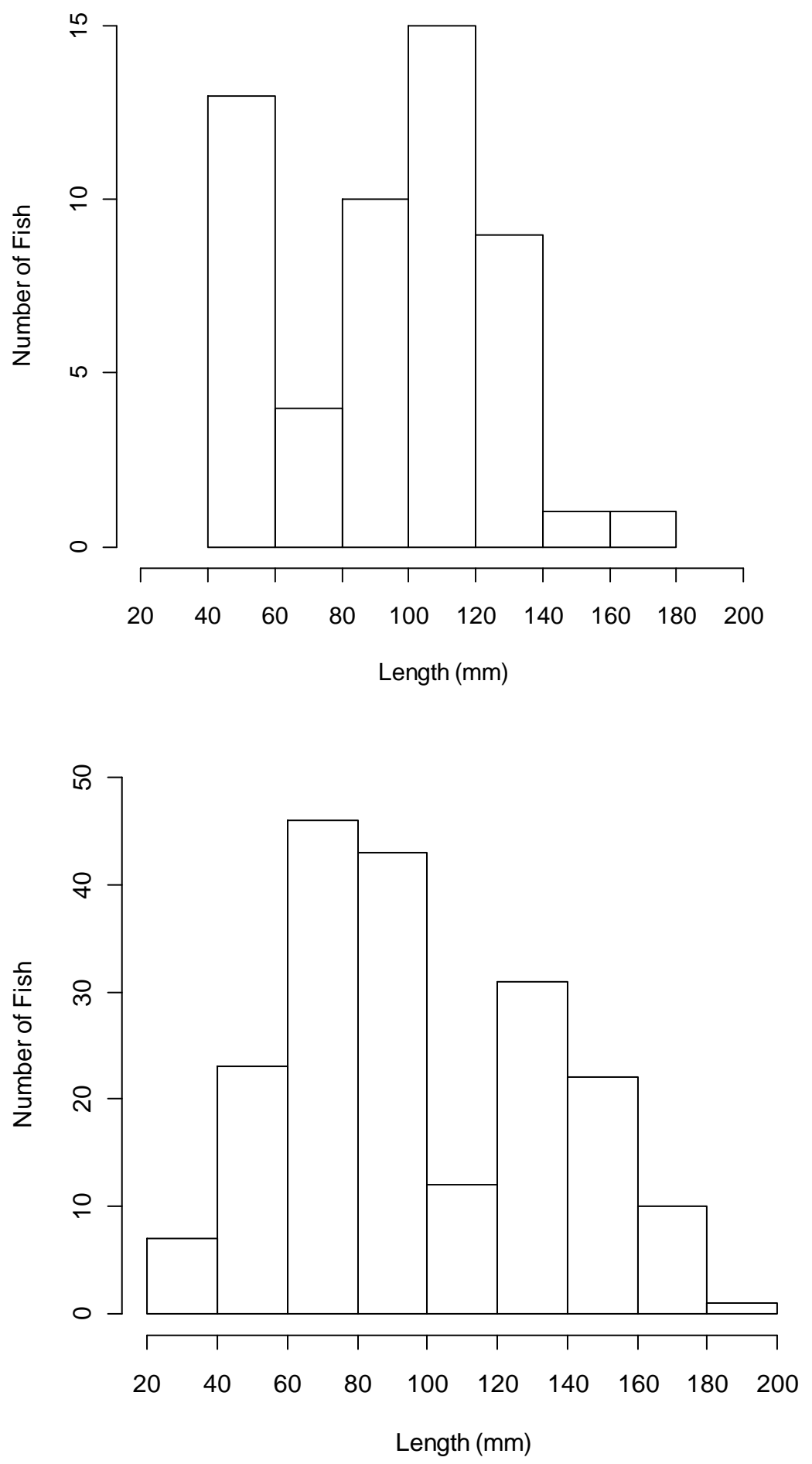

Figure 12: Top graph: Plum Orchard Lake size distribution of bluegill during the 2009 sampling season collected with an electrofishing boat and fyke nets. Adult and juvenile bluegill $(n=53)$ ranged from 40 to $180 \mathrm{~mm}$. Bottom graph: Mud River Reservoir size distribution of bluegill collected during the 2009 sampling period with an electrofishing boat and fyke nets. Bluegill $(\mathrm{n}=195)$ ranged from 20 to $200 \mathrm{~mm}$. 


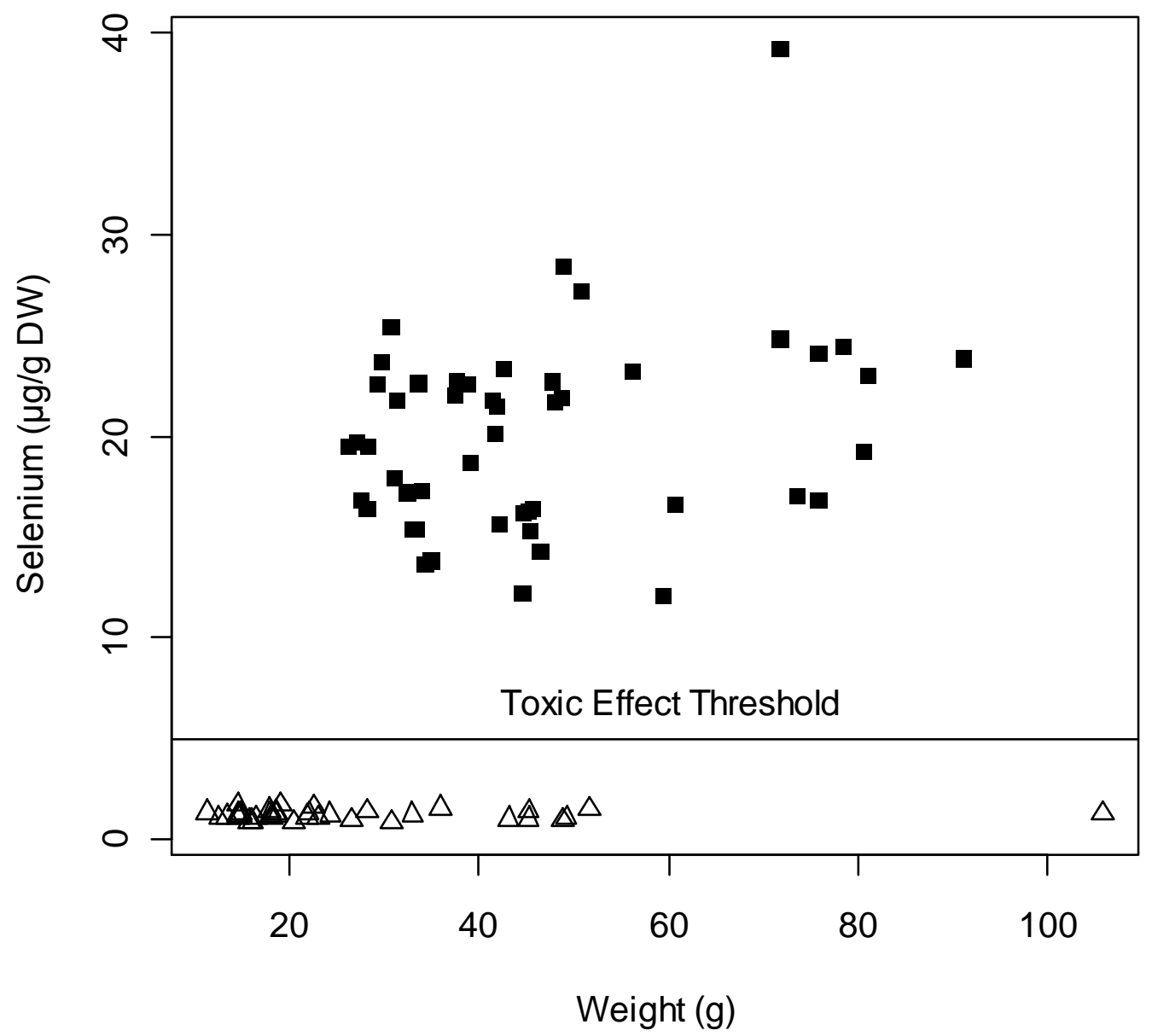

Figure 13: Bluegill whole body selenium concentrations ( $\mu \mathrm{g} / \mathrm{g} \mathrm{DW}$ ) plotted against weight (grams). The bluegill from the reference site (hollow triangles) did not vary much from one another, while the individuals from Mud River Reservoir (solid squares) varied with weight and were greater the Toxic Effect Threshold $(5 \mu \mathrm{g} / \mathrm{g}$ DW). 


\section{Appendix I}

Summary of data from the juvenile bluegill survey conducted in September 2009. Fyke nets were set for approximately $20 \mathrm{hrs}$ and electrofishing pedal time was 3600 seconds. Lengths of fish are presented in the mean \pm standard error.

\begin{tabular}{cccccc}
\hline \multirow{2}{*}{ Site } & \multicolumn{2}{c}{ Fyke Nets } & \multicolumn{2}{c}{ Electrofishing } & \\
\cline { 2 - 5 } & $\begin{array}{c}\text { Number of } \\
\text { Fish }\end{array}$ & $\begin{array}{c}\text { Length } \\
(\mathrm{mm})\end{array}$ & $\begin{array}{c}\text { Number of } \\
\text { Fish }\end{array}$ & $\begin{array}{c}\text { Length } \\
(\mathrm{mm})\end{array}$ & Deformities \\
\hline Mud River Reservoir & 2 & $118 \pm 24.0$ & 146 & $81.5 \pm 2.16$ & 0 \\
Reference & 18 & $57.6 \pm 2.80$ & 240 & $61.4 \pm 1.79$ & 0 \\
\hline
\end{tabular}




\section{Appendix II}

Summary of larval light trapping conducted in July 2009 and 2010. Data represents the overall numbers of each species collected during both sampling periods. No deformities were recorded for both Mud River Reservoir and the reference locations.

\begin{tabular}{ccccc}
\hline & \multicolumn{2}{c}{ Mud River Reservoir } & \multicolumn{2}{c}{ Reference } \\
Species & Larvae & Juvenile & Larvae & Juvenile \\
\hline Lepomis & 6685 & 285 & 23 & 29 \\
Atherinopsidae & 29 & 46 & 0 & 3 \\
Cyprinid & 0 & 0 & 27 & 0 \\
Percid & 0 & 0 & 14 & 0 \\
Unknown & 52 & 0 & 18 & 0 \\
\hline
\end{tabular}

